\title{
Dancing Up the Glass Escalator: \\ Institutional Advantages for Men in Ballet Choreography
}

Colette LaMonica Kelly

(C) 2017 Kelly. This is an open access article distributed under the terms of the Creative Commons Attribution License, which permits the user to copy, distribute, and transmit the work provided that the original author(s) and source are credited. 


\section{Introduction}

A dearth of women exists in the upper echelons of ballet choreography. Both academia and the popular press have noted and documented this phenomenon. For instance, in "Breaking the Glass Slipper," New York Times journalist Michael Cooper recently noted, "When it comes to choreography, at least at most major companies, ballet remains overwhelmingly a man's world." Similarly, critic Luke Jennings has noted, "In professional ballet companies, faced with heavier workloads and greater competitive stress than their male colleagues (not to mention the exigencies of pointe work), few women have the time, energy or inclination to consider choreography."2 And yet many arguments (such as Jennings') as to why women do not become choreographers reflect back on women in ballet - claiming a lack of interest, ambition, or even ability - and fail to acknowledge the structural and systemic inequities that promote men in ballet at the expense of their female peers. Even women choreographers themselves tend to claim that women do not become choreographers because of their own choices, constraints, etc., instead of citing systemic structures of unequal opportunity. ${ }^{3}$ Failing to acknowledge institutional inequality places the fault of discrimination upon its victims, and ignores the gendered hierarchy within ballet institutions. As an alternative, situating ballet choreography in the context of sociological theory can shed light on how institutions promote token men in ballet to artistic leadership positions, and may help disprove the notion that women do not become choreographers simply because of cultural reasons that relate back to the women themselves.

In 1992, sociologist Christine Williams conducted a study of men in four predominantly female professions: nursing, librarianship, kindergarten teaching, and social work. Williams found that while women in male-dominated occupations tend to face considerable obstacles, men in these predominantly female professions benefited from positive attention and mentorship not available to their female colleagues. ${ }^{4}$ Interviews with men in each of these professions revealed a prioritization of their training, hiring, and promotion over that of women to counter-balance societal pressures keeping men out of these professions, but also because men were simply seen as more capable than the women already there. Thus, Williams theorizes that while women in

\footnotetext{
${ }^{1}$ Michael Cooper, "Breaking the Glass Slipper: Where Are the Female Choreographers?," The New York Times, June 23, 2016.

${ }^{2}$ Luke Jennings, "Sexism in Dance: Where Are All the Female Choreographers?," The Guardian (Online), April 28, 2013, 2.

3 "Contemporary Ballet, Women And/As Choreographers" (Contemporary Ballet: Exchanges, Connections, Directions, Barnard College: Society for Dance History Scholars, May 21, 2016).

${ }^{4}$ Christine L. Williams, "The Glass Escalator: Hidden Advantages for Men in the 'Female' Professions," Social Problems 39, no. 3 (1992): 255.
} 
male-typed professions experience a "glass ceiling" of barriers to promotion caused by the sexist attitudes of men in the highest positions, men in predominantly female professions experience a "glass escalator" of invisible pressures to move up in their field. ${ }^{5}$

In my work, I use ballet as a profession to address the fundamental question, what are the institutional mechanisms that favor certain types of people? And further, how do these mechanisms differentially promote certain people to positions of power? Ballet, in its complexity, provides a powerful platform to address how institutions may discourage, discredit, and devalue the work of women who are pursuing positions of authority at the highest level of influence.

Professional ballet in the United States is a predominantly female profession in which men are preferentially promoted to the position of choreographer: $62 \%$ of professional ballet dancers in the nine largest AGMA (American Guild of Musical Artists) signatory companies are women, yet men comprise $85 \%$ percent of the choreographers who create original work for these companies. Thus, the glass escalator model provides a critical lens for studying professional ballet in the United States. Yet in the twenty-four years since Williams conducted her study, no sociologist or dance historian has applied her work to the field of professional dance. This study examines the early choreographic careers of three men in ballet, focusing on paths of advancement that fast track the development of their careers. Such fast-tracking within a single network of ballet institutions does not appear - from the evidence - to apply to women in the same professional organizations, which implies that the dearth of female choreographers in ballet exists (at least in part) for reasons other than those that relate back to the women themselves.

Although the lens of the glass escalator may apply to dance in general, this study will focus specifically on the upper echelon of ballet companies, where the glass escalator is most evident. Whereas the largest ballet companies in the United States tend to be led by men, over two hundred smaller ballet companies exist in the United States as extensions of schools led primarily by women. ${ }^{6}$ The fundamental difference between the predominantly female choreographers for these companies and the predominantly male choreographers for larger companies lies in the scope of their respective roles: Instead of serving solely as choreographers, the women who run these smaller companies perform a role more similar to the ballet masters of the Romantic era, managing and choreographing for the company, teaching, performing administrative tasks, and setting repertory. ${ }^{7}$ Hence the disproportional representation of men in ballet choreography really only applies to the upper tier of companies, which, for the purposes of this paper, will be defined as those companies represented by AGMA that employ 30 or more dancers.

\footnotetext{
${ }^{5}$ Ibid., 256.

${ }^{6}$ Lynn Garafola, "Where Are Ballet's Women Choreographers?," in Legacies of Twentieth-Century Dance (Middletown, Conn: Wesleyan University Press, 2005), 228.

7 Ibid.
} 
The application of Williams' theory to ballet choreography relies on several conditions, which I will attempt to address in this study. First and foremost, the glass escalator model requires that dance is indeed a predominantly female profession. In the statistical analysis of the nine largest AGMA companies, it becomes clear that female professional dancers outnumber male professional dancers, especially upon the inclusion of a "reserve army" of apprentices. Further, Williams' theory deals with inequalities within the same profession. If choreography is a male profession separate from the (predominantly female) profession of performance, then traditional theories of tokenism apply instead of the glass escalator; if, however, performance and choreography exist within the same general profession, the glass escalator may apply. Analysis of the careers of the choreographers profiled here evidence that most choreographers are promoted from within a company or network of companies, and thus that it is possible to address ballet choreography as an extension of the wider field of professional dance. The careers of the women choreographers, however, introduce a complicating dynamic, wherein choreography becomes a sub-field in which women once again assume the position of token minority.

The third condition for the glass escalator, and perhaps the most difficult to prove, is that men are preferentially hired and promoted as ballet choreographers. What are the success rates of men and women in ballet choreography, both in regards to getting hired and to promotion? To answer this question, this study examines how the dynamics identified by Williams, e.g., institutional rules and tracking, supportive networks, and different treatment for men and women in positions of authority, influence the careers of male and female choreographers. Finally, the glass escalator theory states that preferential promotion results from negative cultural stereotypes keeping men out of female professions. Although a full sociology of men in professional ballet would be requisite to fully addressing this question, I will address it on a theoretical level via the work of sociologist Maxine Leeds Craig on social perceptions of dancing men.

\section{Review of Literature and Methodology}

\section{Sociology: Tokenism, the Glass Escalator, and Natural Differences Schemas}

While it is tempting to locate the causes of injury in the actions of the injured, inequality is often just as much - or more - a product of institutional structures than of individual behavior. In Men and Women of the Corporation, sociologist Rosabeth Moss Kanter argues that numerical dominance of a certain type serves to perpetuate structural inequalities. ${ }^{8}$ Kanter defines a "token" as a group that makes up fifteen percent or less of the people within an organization. ${ }^{9}$ As tokens, those in the numerical minority become

\footnotetext{
${ }^{8}$ Rosabeth Moss Kanter, Men and Women of the Corporation (New York: Basic Books, 1993), 221.

${ }^{9}$ Ibid., 209.
} 
stand-ins for all people of that type, and thus must function as symbol, not individual. ${ }^{10}$ This results in three tendencies: visibility, which results in performance pressure, contrast, which results in heightened dominant cultural boundaries, and assimilation, which results in pressures to conform to a specific stereotype. ${ }^{11}$ These tendencies combine to create a self-perpetuating cycle that perpetuates unequal structures of opportunity and keeps people in the position of token.

While Kanter's theory of tokenism is non-specific to gender, class, or race/ ethnicity, Kanter developed it based on the experience of white women in a white-collar corporation; the experience of token (white) men, Williams finds, is different. Token women in predominantly male professions face numerous difficulties, including laws or institutional rules prohibiting the hiring and promotion of women in certain specialties, informal decision-making that results in discrimination in hiring and training, and unsupportive colleagues. ${ }^{12}$ Williams finds that (white) men, however, do not face the same challenges when they enter predominantly female jobs; instead, they may experience an advantage in hiring and promotion. ${ }^{13}$ Importantly, the men in Williams' study did not report sexual harassment or violence on the job, whereas sexual harassment contributes to the "poisoned" work environment often experienced by women in predominantly male professions. ${ }^{14}$

Unlike women entering male-typed occupations, men entering predominantly female occupations experience "discrimination against men in female occupations is discrimination from 'outsiders,' or people outside of the profession or organization itself," Williams writes. ${ }^{15}$ Men tend to be under-represented in female professions because of culturally embedded barriers that prevent men from entering predominantly female occupations. These men may be perceived as feminized, and female professions may be seen as a "step down" from traditionally male occupations. ${ }^{16}$ Because negative stereotypes exist about men in female professions, men tend to avoid flocking to opportunity in these professions.

By moving men into more authoritative positions, organizations may compensate for the negative societal pressures that prevent men from flocking to predominantly female professions. Williams writes that predominantly female institutions may exclude men from certain spheres simply because they are men, or by tracking them into more

\footnotetext{
${ }^{10}$ Ibid., 211.

${ }^{11}$ Ibid., 216.

12 Williams, “The Glass Escalator,” 254.

${ }^{13}$ Ibid., 256.

14 Ibid., 260.

${ }^{15}$ Ibid., 261.

16 Ibid., 262.
} 
authoritative positions, which may be seen as more legitimate for hegemonic men. ${ }^{17}$ This institutional tracking results in men getting "kicked upstairs," and thus their overrepresentation in managerial positions. ${ }^{18}$

Men in female occupations also benefit from alliances with their male supervisors, forming networks not available to their female colleagues. ${ }^{19}$ This is a key difference from women in male occupations: men in female occupations are more likely to be supervised by another man. For men in predominantly female professions, gender is a positive difference, so men bond together to emphasize their distinctness from the female majority. Supportive, collegial relationships with male supervisors allow men to access networks of power in a way that women cannot. ${ }^{20}$

This is not to say that promotions result solely from institutional decision-making, and that individuals have no agency in the path of their own career. Men themselves may also play a role in moving into more authoritative positions within female-dominated occupations: Williams finds that men define their masculinity within a feminized work environment by occupying positions of power, which may be perceived as more "masculine." ${ }^{21}$ Institutional structures of opportunity and promotion, however, exist for men in predominantly female professions, regardless of individual ambition.

To understand inequalities of opportunity and promotion based on gender, regardless of the field, we must first break down the idea that men and women are fundamentally different, and thus naturally suited to different activities. These are called "natural differences schemas," and are perpetuated either directly or indirectly whenever a distinct line is drawn between women and men. Of course, this presents a problem for this study, which accepts this difference as the basis for my analysis. To counteract this, I present here an explanation of why these schemas are inherently flawed, in hopes that the distinction drawn in later chapters between men and women does not provide justification for inequality of opportunity.

In 2005, then Harvard president Larry Summers gave a speech in which he claimed that persistent workplace inequality resulted from inherent differences between men and women. ${ }^{22}$ Sociologist Kristen Schilt calls this a "natural differences" schema, a cultural schema that inequality arises from innate differences between men and women, and thus

\footnotetext{
${ }^{17}$ Williams notes that men who have "feminized" themselves - openly gay men who occupy a feminine gender persona - encounter less upward tracking in organizations (257). The gay male presence, however, is so pervasive in ballet that it likely does not function as an impediment in the same way that it does for Williams' four professions.

18 Williams, "The Glass Escalator," 256.

${ }^{19}$ Ibid., 258.

${ }^{20}$ Ibid., 259.

${ }^{21}$ Ibid., 257.

${ }^{22}$ Kristen Schilt, Just One of the Guys? Transgender Men and the Persistence of Gender Inequality (London: The University of Chicago Press, 2010), 1.
} 
innate differences in their abilities and skills. ${ }^{23}$ These schemas assume that a culturally assigned set of biological characteristics coded as male or female govern an individual's physical abilities, intelligence, reproductive roles, and "emotional landscapes," often with unequal outcomes for men and women. The assumption of natural differences between the capabilities of men and women leads to the conclusion that they are naturally suited for different kinds of work, and thus to entrenched workplace inequality. "Within the gender organization of the workplace," Schilt writes, "men are not assumed to be simply different from women but actually better than women" (emphasis retained from original). ${ }^{24}$ Schilt claims that the fact that the president of an Ivy League institution found this view unproblematic indicates the continuing legitimacy and pervasiveness of this schema.

Natural differences schemas break down, Schilt finds, when the same person receives drastically different treatment as man than as a woman. The transmen that Schilt studied all transitioned from being socially recognized as women ("social women") to being socially recognized as men, or different from women ("social men"). According to Schilt, the resulting "outsider-within" perspective of transmen allows them to see the advantages of being men in the workplace after experiencing the lack of such advantages as women. ${ }^{25}$ Schilt begins her book with the experience of Stanford professor Ben Barres, who experienced more recognition for his scientific work after he changed his name from Barbara to Ben and developed facial hair. ${ }^{26}$ In fact, two thirds of the transmen studied by Schilt reported increases in authority, perceived competence, rewards for their work, and economic opportunity. ${ }^{27}$ Further, the men who embodied the characteristics of hegemonic masculinity - white, tall, and passable - reported more positive changes at work than those who did not fit these characteristics. Since the men who fit society's "hegemonic expectations of masculinity" reported the greatest increase in positive treatment, it follows that persistent gender-based inequality in the workplace does not result from natural differences between men and women, but rather from an ingrained bias toward hegemonic masculinity. ${ }^{28}$

Sociologist Ruth Milkman shows that natural differences schemas also break down when men move into traditionally female jobs, or women enter traditionally male jobs. Changes in the way certain bodies are associated with certain jobs disproves the immutability of this association, providing grounds for its de-naturalization. For example, the movement of women into factory work during World War II "challenged the ideology

\footnotetext{
23 Ibid., 2.

${ }^{24}$ Ibid., 16.

${ }^{25}$ Ibid., 9.

26 Ibid., 132.

${ }^{27}$ Ibid., 16.

28 Ibid.
} 
of 'woman's place,"” writes Milkman, or the assignment of a woman's body to certain types of work, as women moved from reproductive labor to traditionally male-dominated factory work. ${ }^{29}$ Women working in automobile factories had none of the male attributes assigned by the natural differences schema that were assumed to be requisite for performing this labor. Thus, it could be inferred that the women in these jobs disproved the assumption that factory work was “men's work," performed well only by men's bodies.

The resilience of natural differences schemas become apparent in the way that these challenges to the schema are nullified. Women in automobile factory jobs during World War II challenged the natural differences schema by showing that in fact any body could perform the work previously assigned to the bodies of men. However, to uphold "the structure of job segregation by sex and the general ideology of sexual division which legitimates it," government propaganda and the automobile industry simply re-typed the factory jobs held by women as female. ${ }^{30}$ Milkman quotes a propaganda newsreel from 1943:

Instead of cutting the lines of a dress, this woman cuts the pattern of aircraft parts. Instead of baking cake, this woman is cooking gears to reduce the tension in the gears after use .... They are taking to welding as if the rod were a needle and the metal a length of cloth to be sewn. After a short apprenticeship, this woman can operate a drill press just as easily as a juice extractor in her own kitchen. And a lathe will hold no more terrors for her than an electric washing machine. ${ }^{31}$

The government and industry upheld the natural differences schema by recasting previously male-dominated factory jobs as "women's work." 32 The arbitrariness of this justification is evidenced by the fact that such logic could be applied to any job, ${ }^{33}$ and that the factory jobs ceased to be typed as women's work after the war $^{34}$ - as if drill presses and juicers suddenly became dissimilar again once the men returned to the workforce in greater numbers.

The challenge presented by transmen to the natural differences schema is nullified by incorporating these men back into the workplace as precisely that - men. Schilt writes, "when some employers and coworkers learn that a stealth transman did not always live as

\footnotetext{
${ }^{29}$ Ruth Milkman, Gender at Work: The Dynamics of Job Segregation by Sex during World War II (Urbana: University of Illinois Press, 1987), 335.

${ }^{30}$ Ibid., 341.

${ }^{31}$ Ibid.

32 Ibid., 365.

${ }^{33}$ Ibid., 341.

${ }^{34}$ Ibid., 365.
} 
a man, they put effort into maintaining the gender status quo by protecting him as just one of the guys or banishing him from the workplace." ${ }^{35}$ Employers and coworkers either avoid dealing with the challenge to the status quo by pushing transmen out of the workplace and avoiding the issue completely, or else reinforcing the natural differences schema by treating transmen as "just one of the guys" and perpetuating the male/female binary. Because the existence of a male/female binary is predicated on culturally assigned differences between men and women, as long as such a binary exists, Schilt claims, "natural differences schemas deeply linked to biology and tradition will remain untouched, and inequality will continue as business as usual." 36 Although a transman may be the same person before and after transition, he will be socially marked as a different person after transition, deserving of different opportunities and treatment, because he has crossed the male/female binary and become a man.

Ballet, with its sometimes-fixed roles for men and women, presents a field wherein natural differences between men and women may be both implicitly accepted and actively perpetuated. The point of this study is not to locate inherent sexism in ballet movement, if it exists, or even to claim that gender roles in ballet are always fixed. In a field, however, where men and women have their own distinctly divided training and technique, natural differences schemas may become an implicit motivation for unequal opportunity for men and women. My point here is that whereas differences in male and female bodies may exist, ${ }^{37}$ these differences do not justify any difference in opportunity, even in - especially in - professions so closely tied to the body, such as ballet.

Reading Schilt through the trajectories and stories of men and women in ballet choreography reveals the institutional mechanisms whereby gender forms the bases for differential success. We can identify natural differences schemas in the common explanations for the dearth of women in ballet discussed above, that somehow blame the women in ballet for the discrimination against them - that men have some innate desire or ability to choreograph not present in women. What if Barbara Barres, instead of being a Stanford professor, was instead a principal dancer at City Ballet? Upon becoming Ben, this person would not somehow acquire a desire to choreograph that they ${ }^{38}$ did not have before. They would, after all, be the same person, just a man. Barbara-now-Ben would of course have to undergo a drastic shift in training to be able to dance male roles. In light of Schilt's work, however, this change in training has nothing to do with innate qualities of Barbara or Ben as a person. It is, in fact, an institutional mechanism itself for differential

\footnotetext{
35 Schilt, Just One of the Guys?, 90.

36 Ibid., 175.

${ }^{37}$ I refuse to claim that objective differences between male and female bodies $d o$ exist, as the criteria for "male" and "female" bodies have varied considerably, both culturally and temporally.

38 The singular "they" is often criticized as incorrect or non-academic. I do not have a problem with it, however, and believe, actually, that the refusal to acknowledge the singular "they" may be actively invalidating the identity of some individuals.
} 
success, which I will discuss in the conclusion to this study via the Pierre Bourdieu's sociological theory of habitus.

\section{Methodology}

This project consists of three distinct branches of research: statistical analysis of the dancers and choreographers of nine major ballet companies, analysis of the careers of two major male ballet choreographers, and interviews with three female ballet choreographers. Historical newspaper articles were used to trace the careers of choreographers Benjamin Millepied and Justin Peck, and to analyze the factors that contributed to their success. Interviews were conducted with choreographers Gabrielle Lamb, Emery LeCrone, and Helen Pickett, to further identify gendered mechanisms of success in ballet choreography, and ultimately to complicate the glass escalator theory.

For the statistical analysis, dancer and choreographer demographics were collected for the New York City Ballet, American Ballet Theatre, San Francisco Ballet, Pacific Northwest Ballet, Boston Ballet, Houston Ballet, Joffrey Ballet, Ballet West, and Pennsylvania Ballet. The number of male and female dancers at each tier of the company hierarchy (principal, soloist, corps, apprentice) was recorded, as well as total dancers in the company. Apprentices and second companies were not included in the totals for the company, but rather analyzed as a separate group. "Soloist" included those grouped as "first soloist," "soloist," and "demi soloist," according to company websites. Analysis was limited to those AGMA ballet companies with 30 dancers or more, because a company such as NYCB, wherein the corps alone includes 47 dancers, is not necessarily analogous to companies such as the Cincinnati Ballet, which has only 25 members. Thus the cut-off in size is drawn at Pennsylvania Ballet because it is the smallest company for whom the male choreographers analyzed here have created work. ${ }^{39}$

Information on commissions for original work was collected from press releases and season announcements regarding the most recent season. The most recent season is defined as the "2016-17 season," which is how most companies (with the exception of NYCB and ABT) present their upcoming season in press releases to the public. This typically begins with a November/December Nutcracker series, followed by spring and fall seasons the next year. Only original works - world premieres - were analyzed, since these comprise the new commissions for that season.

\section{Background}

Company structure is integral to the discussion of promotion within ballet. The companies analyzed here follow the same hierarchical schemes, with the corps de ballet at the lowest level, followed by soloists, followed by principal dancers. The choreographer occupies a position of artistic authority, wherein the creation of, and credit for, a work rests entirely with him or her (collaboration with dancers may comprise part of the creation of a piece, but this is considered part of the choreographer's greater

\footnotetext{
39 Pennsylvania Ballet also represents the smallest size of company in the Balanchine repertory network. See the analysis of Justin Peck's career for more on this network.
} 
"process," such that the dancers' creative work becomes credited to the choreographer's larger vision). Crediting of choreographers with original works grants to them greater status than most individual performers, if status is measured by name recognition, salary, and artistic authority. The artistic director of a company has the authority to hire or retain choreographers, and in general to shape the aesthetic of the company dancers and the type of work that they perform.

Important to this discussion, too, is the distinction between original and repertory work. Original works represent what the company - the artistic director - is seeking to fulfill the aesthetic and artistic goals of the company at the current moment. Repertory work may reflect that, too, or it may have a certain inertia, such that works that do not reflect the current vision for the company may remain in the repertory, if they are classics, popular with audiences, or a complementary pairing with some other repertory work. An analysis of repertory work, then, while valuable, would not reflect the current hiring practices of a company, as much as it might reflect the company's history and evolution, the types of pieces perceived to be valuable, ${ }^{40}$ and/or even simply the types of work that attract crowds.

Finally, there is a significant distinction between working as a freelance choreographer, and creating commissions for large ballet companies. Freelance choreographers, as we will see in the interviews with the women choreographers, must coordinate the logistics of rehearsal and performance, whereas commissioned choreographers may take advantage of administrative structures already in place. Choreographers creating individual commissioned works, however, must adapt to new dancers, company culture, and ways of rehearsing, whereas freelance choreographers may develop their own group with whom they work on a consistent bases. The resident choreographer overcomes both of these challenges, wherein he or she has the advantage of focusing solely on artistic creation without the additional work of coordinating logistics, as well as working with a consistent group of dancers, within a consistent company framework. As seen below, the opportunity to serve as resident choreographer comprises another mechanism whereby men like Justin Peck receive prioritization of their careers. The lack of recognition of this mechanism renders it invisible.

\section{Statistical Analysis of AGMA Signatory Ballet Companies}

Of the 91 total dancers in NYCB, 59\% are female, while $66 \%$ of the 47 corps members are female. ${ }^{41}$ It was difficult to find information on the NYCB apprentices, but the SAB facebook page listed six new female apprentices in $2013 .{ }^{42}$ It was assumed that

\footnotetext{
40 This, too, may be tied to gender.

41 “NYCB - Dancers,” accessed March 13, 2017, http://www.nycballet.com/Discover/Dancers.aspx\#rank.

42 “The School of American Ballet - Timeline," Facebook, accessed March 26, 2017, https:// www.facebook.com/SABNYC/photos/a.399587493869.183424.36603863869/10151788203893870/? type $=1 \&$ theater.
} 
this was roughly representative of the NYCB apprentice pool. NYCB presented original works by Christopher Wheeldon and Nicolas Blanc in their spring 2016 gala, ${ }^{43}$ and original works by Lauren Lovette, Annabelle Lopez Ochoa, Peter Walker, and Justin Peck in their fall 2016 gala. ${ }^{44}$ NYCB presented original works by Justin Peck and Pontus Lidberg in their winter 2017 season. ${ }^{45}$ NYCB will present original works by Alexei Ratmansky and Justin Peck in their spring 2017 season. ${ }^{46}$ Justin Peck is the resident choreographer at NYCB.

Of 89 total dancers in American Ballet Theatre (ABT), $57 \%$ are female, and $62 \%$ of the 59 corps members are female. ${ }^{47}$ ABT currently employs six apprentices, four of whom are women. ABT's spring 2016 season at the Metropolitan Opera House featured one original work, by Alexei Ratmansky, ${ }^{48}$ while their fall season at the David Koch Theater featured an original work by Jessica Lang. ${ }^{49}$ ABT's spring 2017 season will present another original work by Ratmansky. ${ }^{50}$ Alexei Ratmansky is ABT's resident choreographer.

San Francisco Ballet employs 70 total dancers and five apprentices. The company is $55 \%$ female, and the corps is $62 \%$ female. San Francisco Ballet's apprentices include three men and two women. San Francisco Ballet included four original works in its 2016-2017 season. These included "Fragile Vessels" by Jiri Bubeníček, "Optimistic Tragedy" by Yuri Possokhov, "Salome" by Arthur Pita, and "Ghost in the Machine" by Myles Thatcher. ${ }^{51}$

\footnotetext{
43 Communications Department, "New York City Ballet Presents 2016 Spring Season Performances," March 30, 2016, https://www.nycballet.com/NYCB/media/NYCBMediaLibrary/PDFs/Press/ 2016-03-24_2016-17-Season-Announcement.pdf.

44 Communications Department, "New York City Ballet Announces 2016-17 Season," March 24, 2016, https://www.nycballet.com/NYCB/media/NYCBMediaLibrary/PDFs/Press/2016-03-24_NYCB_2016-17Season-Announcement.pdf.

45 Ibid.

46 Ibid.

47 “ABT: Dancers,” accessed March 13, 2017, http://www.abt.org/dancers/default.asp?section=principal.

48 “ABT: Inside ABT,” accessed March 13, 2017, http://www.abt.org/insideabt/news_display.asp? News_ID $=534$.

49 BWW News Desk, “American Ballet Theatre Announces 2016 Fall Season,” BroadwayWorld.com, accessed March 13, 2017, http://www.broadwayworld.com/article/American-Ballet-TheatreAnnounces-2016-Fall-Season-20160713.

${ }^{50}$ BWW News Desk, “American Ballet Theatre's 2017 Spring Season at the Metropolitan Opera House Announced," accessed March 14, 2017, http:/www.broadwayworld.com/bwwdance/article/AmericanBallet-Theatres-2017-Spring-Season-at-the-Metropolitan-Opera-House-Announced-20161025.

51 “Repertory Season,” San Francisco Ballet, accessed March 26, 2017, https:/www.sfballet.org/season/ repertory.
} 
Boston Ballet employs 56 dancers, $54 \%$ of whom are female. ${ }^{52}$ Its 26 -member corps is $46 \%$ female. Boston Ballet II, which is functionally a paid apprentice troupe, has six women and six men. ${ }^{53}$ In its 2016-2017 season, Boston Ballet premiered one original work by its resident choreographer, Jorma Elo. ${ }^{54}$

Houston Ballet employs 51 dancers, $51 \%$ of which are female. ${ }^{55}$ Houston Ballet has a corps of 21 dancers, $52 \%$ of which is female. Houston Ballet's apprentices include five women and two men. ${ }^{56}$ Houston Ballet did not commission any original works for its 2016-17 season. ${ }^{57}$

The Joffrey Ballet employs 44 total dancers, $45 \%$ of whom are female. ${ }^{58}$ Joffrey does not divide company members into principal, soloist, corps de ballet, etc. on its website, so these statistics were not collected for Joffrey. Joffrey does not have apprentices, but does have an unpaid studio company, comprised of six women and five men. ${ }^{59}$ The Joffrey Ballet presented one original work in its 2016-17 season, "Episode 47!" by Alexander Ekman. ${ }^{60}$

Pacific Northwest Ballet (PNB) also employs 44 dancers, $52 \%$ of whom are female. ${ }^{61} \mathrm{PNB}$ has a corps of 21 dancers, $52 \%$ of which is female. PNB has three apprentices, all of whom are women. ${ }^{62}$ PNB commissioned one new work for its 2016-17 season: "Her Door to the Sky" by Jessica Lang.

Ballet West employs 40 total dancers, $58 \%$ of whom are women. ${ }^{63}$ Ballet West has a corps of 18 dancers, $67 \%$ of which is female. Ballet West II is comprised of six women

\footnotetext{
52 “Boston Ballet - The Company | Dancers,” accessed March 26, 2017, https:/www.bostonballet.org/ Home/The-Company/Dancers/FullCompany.aspx.

53 “Boston Ballet - The Company | BBII Dancers," accessed March 26, 2017, https://www.bostonballet.org/ Home/The-Company/Dancers/Boston-Ballet-II/BBII-Dancers.aspx.

54 Boston Ballet Media Department, “Boston Ballet Announces 2016-2017 Season,” February 17, 2016.

55 “Houston Ballet | Dancers,” accessed March 26, 2017, https://www.houstonballet.org/explore/artists/.

56 Ibid.

57 “Houston Ballet | 2016-17 Season,” accessed March 26, 2017, https://www.houstonballet.org/ seasontickets/2016-2017-season/.

58 “2016-2017 Dancers | Joffrey Ballet,” accessed March 26, 2017, http://www.joffrey.org/1617dancers.

59 “Studio Company | Joffrey Ballet,” accessed March 26, 2017, http://joffrey.org/studiocompany.

60 “Global Visionaries | Joffrey Ballet,” accessed March 26, 2017, http://www.joffrey.org/global.

61 “Artists - The Dancers at Pacific Northwest Ballet in Seattle," Pacific Northwest Ballet, June 19, 2015, https://www.pnb.org/artists/.

62 Ibid.

63 “Dancers: Ballet West,” accessed March 26, 2017, https://balletwest.org/dancers.
} 
and six men. ${ }^{64}$ Ballet West commissioned two new original works for its 2016-17 choreographic festival, by Nicolo Fonte and Val Caniparoli. ${ }^{65}$ In addition, Ballet West will present four new works by company members in their 2017 "Works from Within" festival, all by men. ${ }^{66}$

Pennsylvania Ballet employs 34 dancers, $53 \%$ of whom are female. ${ }^{67}$ Pennsylvania Ballet has a corps of 22 dancers, $55 \%$ of which is female. Of its eight apprentices, six are women. ${ }^{68}$ In its 2016-17 season, Pennsylvania Ballet commissioned three new works, from Brian Sanders, Nicolo Fonte, and Matthew Neenan, who is the resident choreographer for the company. ${ }^{69}$

The statistics for these nine companies provide evidence that ballet is predominantly female profession. When calculating the number of female dancers as a percentage of all dancers in the nine companies, $55.2 \%$ of the total professional dancers - excluding apprentices - are women. But when including apprentices, $62.1 \%$ of the dancers in these nine companies are women. The average percentage of female dancers, including apprentices, is significantly greater than the average when excluding apprentices (paired independent samples t-test, $\mathrm{p}<0.01$, critical value $=0.05$ ) (Table 1 ). Women comprise an average of $54.5 \pm 3.7 \%$ of total dancers when excluding apprentices. When including apprentices, however, women comprise an average of $61.5 \pm 4.1 \%$ of the company dancers.

Table 1: Effect of apprentices on company composition. Mean and standard deviations are shown for the percentage of female dancers in the nine largest AGMA ballet companies, with and without apprentices included in the analysis. The mean percentage of female dancers is significantly greater when apprentices are included.

\begin{tabular}{|l|l|l|}
\hline & $\begin{array}{l}\text { Total }+ \\
\text { Apprentice } \\
\text { \% female }\end{array}$ & \% female \\
\hline Mean & 61.488397 & 54.46008187 \\
\hline Std. Dev. & 4.068613119 & 3.688537416 \\
\hline
\end{tabular}

${ }^{64}$ Ibid.

65 “Ballet West Announces 2016-17 Season - Dance Informa USA,” accessed March 26, 2017, http:// www.danceinforma.us/articles/ballet-west-announces-201617-season/.

66 "Ballet West Launches New Works From Within: Ballet West," accessed March 26, 2017, https:// balletwest.org/news/ballet-west-launches-works-from-within.

67 “Dancers | Pennsylvania Ballet,” accessed March 26, 2017, http://www.paballet.org/dancers.

${ }^{68}$ Ibid.

69 Pennsylvania Ballet Communications Department, "Pennsylvania Ballet Announces Revolutionary 2016-2017 Season," March 3, 2016. 


\section{\begin{tabular}{l|l} 
p-level & $\mathbf{0 . 0 0 1 1 1}$
\end{tabular}}

This indicates that while companies have roughly similar numbers of male and female dancers in the professional divisions, apprentices represent a "reserve army" of female dancers for companies to utilize for ballets that require a large number of female corps members, such as Swan Lake, Giselle, or Nutcracker. It also indicates that whereas companies may try to maintain roughly parity between men and women on their official rosters, when including the entire labor base, ballet performance is primarily a female profession.

For these nine companies, most of the women are employed in the corps de ballet. Female corps members represent the largest group of dancers: there are significantly more women in the corps than at any other level of company hierarchy (Figure 1). There are an average of $19 \pm 10$ female corps members in each company (the large error exists due to the highly variable size of each company, from 34 dancers in Pennsylvania Ballet to 91 total dancers in NYCB) (Figure 1). This is likely because certain repertory, including $19^{\text {th }}$ century Romantic ballets as well as many works by Balanchine, use large female ensembles, with few analogous ensembles for men.

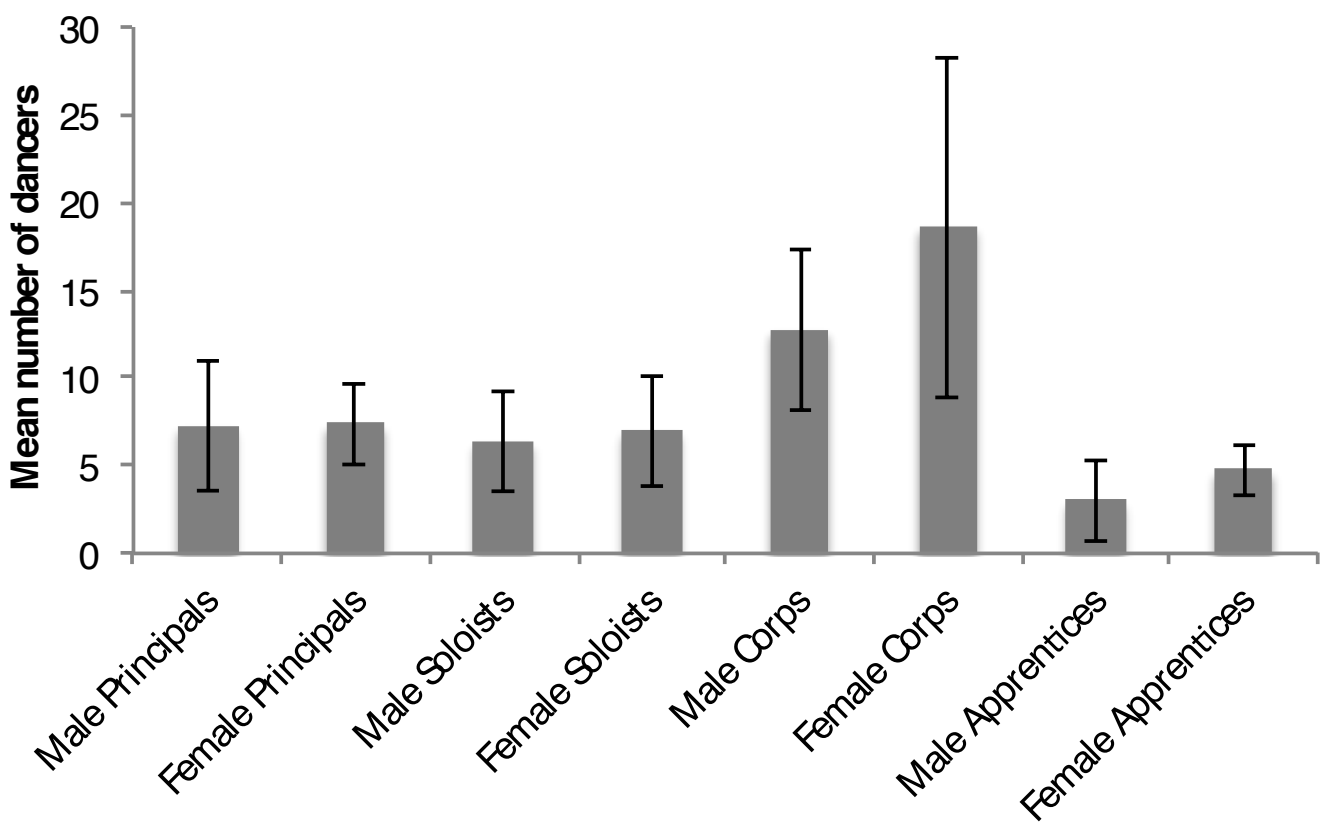

Figure 1: Mean number of dancers at each level of company hierarchy. Bars represent the mean number of male and female dancers, respectively, at each level of company hierarchy in the nine largest AGMA ballet companies $(n=9)$. Error bars represent one standard deviation. The mean number of female corps members is significantly greater than any other group, other than male corps members. 
Men comprise the overwhelming majority of the choreographers for these companies. A total of 22 men and four women were commissioned to create original work for the nine companies in their 2016-17 season, representing 25 original works by men and four original works by women (the number of original works by men is greater than the number of men creating original work, because many of these companies have male resident choreographers, who may create multiple works per season). The average number of commissioned male choreographers was significantly greater than the average number of women (paired independent samples t-test, $p=0.03$, critical value $=0.05$ ). The average number of commissioned male choreographers was $2.4 \pm 2.3$, and the average number of commissioned female choreographers was $0.4 \pm 0.7$ (Table 2) ${ }^{70}$ Although the error in these two numbers overlaps, the t-test indicates that they are still significantly different. This stands in contrast to the statistics on the performers, who are predominantly female.

Table 2: Difference between mean male and female commissioned choreographers. Mean and standard deviations are shown for the number of commissioned choreographers for the nine largest AGMA ballet companies in the 2016-17 season, divided by men and women. The mean number of male choreographers is significantly greater than the mean number of female choreographers.

\begin{tabular}{|l|l|l|}
\hline & $\begin{array}{l}\text { Male } \\
\text { Choreographers }\end{array}$ & $\begin{array}{l}\text { Female } \\
\text { Choreographers }\end{array}$ \\
\hline Mean & 2.4 & 0.4 \\
\hline Std. Dev. & 2.3 & 0.7 \\
\hline & p-level & $\mathbf{0 . 0 3 4}$ \\
\hline
\end{tabular}

Finally, there is a significant difference between the percentage of female choreographers and female dancers (paired independent samples t-test, $\mathrm{p}<0.01$, critical value $=0.05$ ). The mean percentage of women dancers is $61.5 \pm 4.1 \%$, whereas the mean percentage of women choreographers is $21.9 \pm 34.15 \%$ (Table 3 ).

Table 3: Difference between mean male and female commissioned choreographers. Mean and standard deviations are shown for the percentage of female dancers and female

\footnotetext{
${ }^{70}$ Although half of a person does not really make sense, it is useful in statistical comparison.
} 
choreographers for the nine largest AGMA ballet companies in the 2016-17 season.

Dancers make up a significantly greater proportion of the dancers than of choreographers.

\begin{tabular}{|l|l|r|}
\hline & $\begin{array}{l}\text { \% female } \\
\text { dancers }\end{array}$ & $\begin{array}{l}\text { \% female } \\
\text { choreographers }\end{array}$ \\
\hline Mean & 61.488397 & 21.875 \\
\hline Std. Dev. & 4.068613119 & 34.08972536 \\
\hline & p-level & $\mathbf{0 . 0 0 6 5 3}$ \\
\hline
\end{tabular}

As a fraction of the total dancers and choreographers across all nine companies, women represent $62 \%$ of the total dancers (including apprentices) but only $15 \%$ of the commissioned choreographers in the 2016-2017 season. Thus, while women comprise the majority of the performers in these nine companies, they are a small minority of the choreographers (Figure 2).

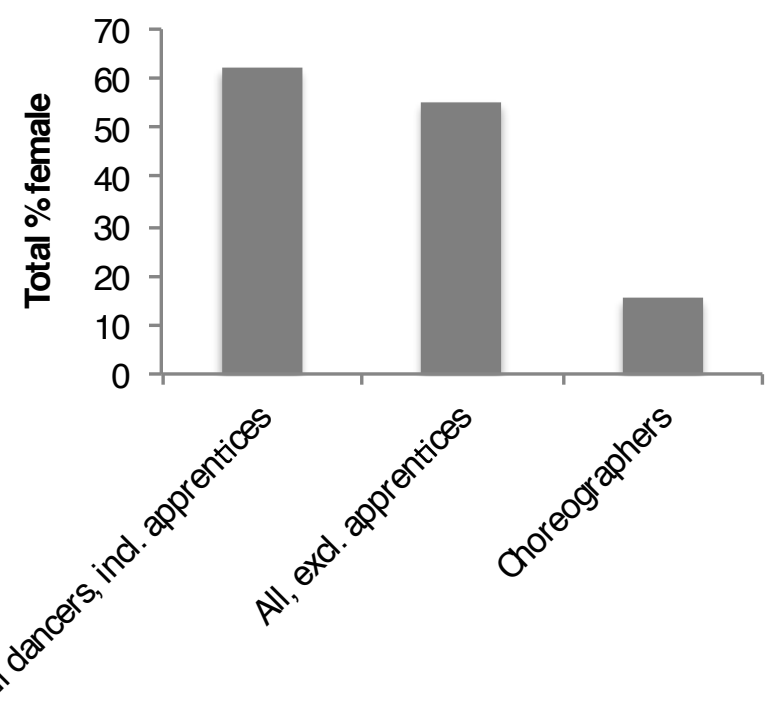

Figure 2: Percentage of female dancers and choreographers in the nine largest AGMA ballet companies. Bars represent the percentage of female dancers and choreographers for the nine largest AGMA ballet companies $(n=9)$. While women comprise the majority of dancers, they comprise the minority of choreographers for these companies.

The statistics above show clearly that men are disproportionately promoted to the position of choreographer: the proportions of male and female dancers and male and female choreographers are significantly different, for these nine companies. To identify the mechanisms that cause this disproportionality, it is necessary to examine the careers 
of individual choreographers, to locate the mechanisms that facilitated, or failed to facilitate, their success.

\section{Career Trajectories of Male Choreographers}

Williams writes that predominantly female institutions compensate for negative external pressure from society by tracking men into more authoritative positions, or "kicking them upstairs." "T1 The career trajectories of male choreographers provide evidence that institutional tracking provides a mechanism for the preferential promotion of men to the higher-status position of choreographer, as well as providing evidence that choreographers are promoted from within a company, or network of companies.

The career of Justin Peck, current resident choreographer of the New York City Ballet (NYCB), presents a clear example of institutional promotion of certain choreographers. Peck joined the corps of NYCB in 2007, and in 2009, was selected from a pool of applicants to participate in the New York Choreographic Institute, a satellite organization of NYCB. ${ }^{72}$ In 2011, Peter Martins, artistic director of NYCB, selected Peck to receive the company's first yearlong choreographic residency. ${ }^{73}$ Since then, Peck has choreographed numerous commissioned works for NYCB, as well as for various regional dance companies, the Paris Opera Ballet, the School of American Ballet, City Center's Fall for Dance, and the Guggenheim Museum. ${ }^{74}$ In 2014, Martins named Peck NYCB's resident choreographer, second in the company's history after Christopher Wheeldon. ${ }^{75}$

Since his residency in 2011, Peck has choreographed ten commissioned works for NYCB ${ }^{76}$ Peck's first commission, In Creases, premiered in 2012 at the Saratoga Performing Arts Center with NYCB Moves, the company's touring ensemble. ${ }^{77}$ Immediately after the premiere of In Creases, Peck created another work for NYCB, Year of the Rabbit. ${ }^{78}$ Before his designation as resident choreographer, Peck created Paz de la Jolla and Capricious Maneuvers for NYCB in 2013, as well as Take-Offs and Landings for Ballet Moves; and then Everywhere We Go in 2014. Since being named resident

\footnotetext{
${ }^{71}$ Williams, "The Glass Escalator," 257.

72 “Justin Peck," accessed November 12, 2016, http://www.nycballet.com/Dancers/Dancers-Bios/JustinPeck.aspx.

${ }^{73}$ Ibid.

74 Elise Taylor, “Is Justin Peck Making Ballet Cool Again?," Vanity Fair, April 6, 2016, http:// www.vanityfair.com/culture/2016/04/justin-peck-ballet-cool-in-the-countenance-of-kings; "Justin Peck."

75 Taylor, “Is Justin Peck Making Ballet Cool Again?”; “Justin Peck.”

76 Claudia La Rocco, “Justin Peck Choreographing for NYCB,” The New York Times, July 27, 2012.

${ }^{77}$ Ibid.

78 "Justin Peck."
} 
choreographer, Peck has choreographed Belles-Lettres for NYCB in 2014; Rodeo - Four Dance Episodes and New Blood in 2015; and The Most Incredible Thing in 2016. ${ }^{79}$

In addition to his work for NYCB, Peck has created works for Miami City Ballet, L.A. Dance Project, Pacific Northwest Ballet, and San Francisco Ballet. In March 2013, Lourdes Lopez, artistic director of Miami City Ballet, commissioned Peck to create Chutes and Ladders during a two-week residency with the company. ${ }^{80}$ Later that year, Peck was commissioned to create Murder Ballades for the L.A. Dance Project. ${ }^{81}$ In 2014, Peck created Debonair for the Pacific Northwest Ballet, ${ }^{82}$ and in 2015, Peck was commissioned by Miami City Ballet again to create Heatscape. ${ }^{83}$ After creating The Most Incredible Thing for NYCB in February 2016, Peck created In the Countenance of Kings for the San Francisco Ballet in April, ${ }^{84}$ followed by Helix for the L.A. Dance Project in July. ${ }^{85}$ Also in 2016, Peck created Entre Chien et Loup for the Paris Opera Ballet. It was performed alongside his earlier work, In Creases, while NYCB performed Year of the Rabbit at the Théâtre du Châtelet. ${ }^{86}$

There are no discontinuities in Peck's choreographic career - each commission seems to lead to more commissions, for NYCB, regional companies, and abroad. This seems to have been sparked by Peck's initial participation in the New York Choreographic Institute and residency with NYCB before the creation of In Creases in 2012. Both of these were a product of institutional selection, primarily by Peter Martins, thus comprising an institutional mechanism for Peck's initial success. Peck's continuing success may, of course, have resulted primarily from his talent as a choreographer: New York Times critic Brian Seibert writes of "critical assessments that place [Peck] at the very top of ballet choreographers." 87

\footnotetext{
${ }^{79}$ Ibid.

80 “Imagining 'New Work’ with Justin Peck,” Miami City Ballet, March 20, 2013.

${ }^{81}$ Alastair Macaulay, “A Return Back East to Make a Debut: L.A. Dance Project Brings Millepied and Peck Works to BAM," The New York Times, October 17, 2014.

${ }^{82}$ Gia Kourlas, "Carefree, but Decorous All the Same: Pacific Northwest Ballet Presents 'Debonair," The New York Times, October 10, 2014.

${ }^{83}$ Alastair Macaulay, "Review: Miami City Ballet in 'Heatscape,' a Fleeting Chase of Romance," The New York Times, March 29, 2015.

${ }^{84}$ Carla Escoda, “Justin Peck's In the Countenance of Kings Debuts in San Francisco to Great Fanfare," Huffington Post, April 8, 2016.

85 Alastair Macaulay, "Review: L.A. Dance Project's Eclectic Balancing Act," The New York Times, July 27, 2016; Brian Seibert, "Justin Peck Calmly Creates a Kingdom at NYCB," The New York Times, January 29, 2016.

${ }^{86}$ Roslyn Sulcas, "Review: In Paris, a Bold Ballet Adventure From Justin Peck," The New York Times, July 13, 2016.

${ }^{87}$ Seibert, "Justin Peck Calmly Creates a Kingdom at NYCB."
} 
Regional companies likely fast-tracked Peck's career by providing a space for him to develop as a choreographer, with lower stakes than his commissions from Martins. The commissions for these companies often premiered alongside the work of other choreographers associated with NYCB, including Balanchine, Robbins, Wheeldon, and Millipied. Murder Ballades for the L.A. Dance Project premiered alongside Benjamin Millepied's Reflections (2013) and William Forsythe's Quintett (1993). Debonair for the Pacific Northwest Ballet premiered next to Wheeldon's Tide Harmonic (2013) and new work by Alejandro Cerrudo; Heatscape for the Miami City Ballet shared a program with Balanchine's Raymonda Variations (1962) and Robbins' The Concert (1956). Helix for the L.A. Dance Project was performed next to Millepied's On the Other Side, as well as work by Sidi Larbi Cherkaoui and duets from Martha Graham's A Dancer's World ${ }^{88}$ In the Countenance of Kings for the San Francisco Ballet shared a program with Balanchine's Theme and Variations and Wheeldon's Continuum (2002). ${ }^{89}$ As evidenced by their NYCB-centric repertory, the smaller companies for whom Peck has choreographed belong to a regional network connected back to NYCB through their repertory and artistic leadership.

Peck's continuing success may, of course, have resulted primarily from his talent as a choreographer. This talent, however, is in and of itself a product of institutional mechanisms, whereby choreographic talent is ultimately a product of practice, and practice is directly tied to opportunity. If access to this network allowed Peck to experiment, and perhaps fail, outside of the NYCB framework, then this network allowed him to develop as a choreographer and thus provided a mechanism for his promotion to resident choreographer for NYCB.

Benjamin Millepied provides another example of a highly successful male choreographer in ballet. Millepied moved from NYCB corps member to principal dancer to internationally recognized choreographer, and now has his own company in Los Angeles. Millepied's talent as a choreographer likely engendered much of his success, but his early career success, like Peck's, would not have been possible without the support and prioritization of the institutions he encountered.

After receiving most of his early training in France, Millepied moved to New York City at age sixteen to attend the School of American Ballet. ${ }^{90}$ In 1994, as a student at the School, Millepied originated a role in Jerome Robbins' Two- and Three-Part

\footnotetext{
88 Macaulay, “Review,” July 27, 2016.

${ }^{89}$ Escoda, “Justin Peck's In the Countenance of Kings Debuts in San Francisco to Great Fanfare.”

90 “Benjamin Millepied," Opéra National de Paris, accessed November 15, 2016, https:// www.operadeparis.fr/en/3e-scene/contributors/benjamin-millepied.
} 
Inventions.${ }^{91}$ Millepied joined the company in $1995,{ }^{92}$ and was named principal dancer in 2002. ${ }^{93}$ Peter Martins invited Millepied to participate in the New York Choreographic Institute in 2002 and 2003. ${ }^{94}$ As a result, Millepied choreographed his first professional work, Triple Duet, in 2002 as part of an evening of works by NYCB dancers at Sadler's Wells Theatre in London. ${ }^{95} \mathrm{He}$ founded his own company, Danses Concertantes, which performed in Europe and the Hamptons. ${ }^{96}$ In 2005, Martins commissioned Millepied to choreograph Double Aria for two NYCB dancers, as well as 28 Variations on a Theme for the School of American Ballet. ${ }^{97}$ Millepied went on to create works for Sadler's Wells, as wells as for the American Ballet Theatre's Studio Company, Mikhail Baryshnikov (a collaboration with Olivier Simola), American Ballet Theatre, Pacific Northwest Ballet, Het National Ballet, the Metropolitan Opera, Pennsylvania Ballet, Ballet of the Mariinsky Theatre, and the Paris Opera Ballet. ${ }^{98}$ In 2011, Millepied retired from dancing with NYCB to start the L.A. Dance Project..$^{99}$ In 2014, Millepied became the director of the Paris Opera Ballet, but stepped down in July 2016 to return to the L.A. Dance Project. ${ }^{100}$

Millepied's first work, Triple Duet, shared a program with works by Wheeldon, Robbins, and Balanchine, ${ }^{101}$ suggesting that Millepied belonged to an elite, male line of NYCB choreographers. Millepied also benefited from increased visibility and mentorship from male colleagues. In 2005, New York Times critic Anna Kisselgoff wrote, "Along the way, a long line of mentors, including Jerome Robbins and teachers in his native France, plucked [Millepied] out of the crowd."102 Of Danses Concertantes, Kisselgoff writes,

\footnotetext{
${ }^{91}$ Anna Kisselgoff, "A Robbins Premiere With a Cast To Match Its Youthful Outlook: [Review]," The New York Times, June 6, 1994, sec. C.

92 Anna Kisselgoff, "Dewdrop Reigns in the Land of Sweets and Dreams," The New York Times, December 6,1995 , sec. C.

${ }^{93}$ Rebecca Mead, "Bounding Ambition: Profiles," The New Yorker, August 5, 2013.

94 Anna Kisselgoff, “A Dancer Comes Into His Own,” The New York Times, April 5, 2005.

95 "Balanchine: A Principal Year," Pointe, October 2003.

96 Mead, "BOUNDING AMBITION."

${ }^{97}$ Kisselgoff, “A Dancer Comes Into His Own.”

98 “Benjamin Millepied," Opéra National de Paris, accessed November 15, 2016.

${ }^{99}$ Mead, "BOUNDING AMBITION."

100 Marina Harss, "Benjamin Millepied Left the Paris Opera Ballet. Now What?," The New York Times, July 15, 2016.

101 "Balanchine."

102 Kisselgoff, “A Dancer Comes Into His Own.”
} 
"Mr. Martins's invitation to participate in City Ballet's New York Choreographic Institute in 2002 and 2003 coincided with a tip to Mr. Millepied's Danish girlfriend... that Sadler's Wells Theater in London would welcome a small touring group."103 This particular instance suggests the importance of informal networks in providing choreographic opportunity and further, the specificity of these networks in providing opportunity to a particular individual or select group.

For both Millepied and Peck, the next steps in their early careers were always there for the taking. Neither had to scramble for work, or search for opportunities instead, informal networks provided a continuous series of commissions that allowed them to develop their skills and reputation. For these men, the path to choreographic success had a logic; it was clear, well-lit, and supported by those in charge (such as Peter Martins). In addition, Millepied and Peck had access to the privileges of working for large companies: access to very highly trained and highly experienced dancers, access to large casts, and the choice to do chamber work or to work with a large ensemble. These privileges also include access to live music, musical commissions, or virtually any score they want to use. Finally, they benefit from feedback and attention from critics who would not review smaller companies. As we will see in the next section, this is not always - or perhaps ever - the case with choreographers outside the anointed few - and yet this discrepancy is often overlooked, perpetuating the belief that the natural differences between male and female choreographers is the sole driver for the former's success.

\section{Interviews with Female Choreographers}

The careers of the women choreographers interviewed for this study stand in contrast to the careers of the men profiled above. The following interviews with choreographers Gabrielle Lamb, Emery LeCrone, and Helen Pickett attempt to identify structural mechanisms that influenced their careers. Each of these women occupies a different place in the career trajectory of a ballet choreographer, providing different points of contrast with the male choreographers profiled above; at the same time, certain themes emerge, common to all three women, including extra administrative work to make their artistic work possible, a more complex career trajectory than those of the men, and an individuality that defies the conformity of the corps. These common threads provide evidence for, and complicate, the presence of the glass escalator in ballet choreography.

Gabrielle Lamb is a dancer and choreographer based in New York City, who has created ten commissioned works for dance companies in the United States and Canada over the last eight years, as well as participating in various choreography competitions. As a performer, Lamb spent several years as a soloist with Les Grands Ballets Canadiens de Montreal, after dancing with the Boston and Cleveland Ballets, Prague State Opera, and Finnish National Ballet. ${ }^{104}$ Notably, Lamb turned down admission to Harvard at age

103 Ibid.

104 “Gabriellelamb-Pwd | Bio,” Gabriellelamb-Pwd, accessed April 26, 2017, https:// www.pigeonwingdance.com/bio. 
sixteen, while at the Boston Ballet School, in favor of pursuing a career in ballet. ${ }^{105} \mathrm{My}$ interview with Lamb highlighted the presence of an invisible, second job comprised of the administration work inherent in managing her own company, which stands in contrast to the ability of the male choreographers profiled above to focus solely on their creative work.

Emery LeCrone is a choreographer and dancer also based in New York City, who has been creating work for schools, companies, and her own group for ten years. LeCrone currently self-identifies as a ballet choreographer, and likewise identifies her work as contemporary ballet. While she can - and has - worked with dancers principally trained in contemporary movement, as well as with "strict ballet companies," LeCrone prefers to work with "dancers with a classical background who understand weight sharing and floor work. "Ballet is a huge part of what I use," LeCrone says, "and what I want to use," so her work lies solidly within the world of ballet. ${ }^{106}$ In her interview, LeCrone spoke of the difficulty of freelancing, the conformitive pressure of training to become a member of the corps de ballet, and the need to continue to actively seek out work, even after a decadelong career as a choreographer.

Helen Pickett has created more than thirty-five works for companies both in the United States and abroad over the last twelve years, and recently served as resident choreographer for the Atlanta Ballet. Previous to choreographing, Pickett danced with William Forsythe's Ballet Frankfurt for more than ten years, as well as working with the Wooster Group, an avante-garde theater company. Helen Pickett's career illustrates what women in ballet choreography have done, or may do, to compensate for the institutional tracking enjoyed by men. Pickett also highlights the embodied control of ballet institutions over the bodies of dancers - the same "conformity of the corps" noted by LeCrone.

\section{Administration as a Second Job}

The differences between freelancing and choreographing for large companies both present, and are symptomatic of, the difference in the careers of Lamb and the choreographers profiled in the previous chapter. The administrative burden comprises an entire second job for Lamb, which requires time and energy above and beyond that spent creating dances. When we spoke last fall, Lamb was putting together her first concert of entirely her own work, and was doing all of her own administrative work: coordinating dancers' schedules, finding and renting space, getting liability insurance, and communicating with concert organizers. Lamb told me, "doing all the administration is just really challenging; dealing with contracts, trying to stay organized enough that I don't keep on forgetting things, and I feel like my brain is a sieve right now."107 Putting

\footnotetext{
105 Ibid.

${ }^{106}$ Emery LeCrone, interview with the author, New York City, November 18, 2016.

107 Gabrielle Lamb, interview with the author, New York City, October 30, 2016.
} 
together a rehearsal schedule to accommodate the personal calendars of seven individuals consumed a significant amount of Lamb's time. She spoke of color-coded Google calendars with available space and her dancers' commitments to other dance jobs, Pilates teaching, and even jobs as food stylists, Windex-ing plates.

From our interview, it seemed that the jobs of administration and choreography were sometimes at odds. Lamb described to me an instance wherein the work of coordinating rehearsal logistics detracted from her work as a choreographer in rehearsal:

It was so awful, last week, I had a day where I was rehearsing with this, seven long hours sitting in Queens, with a couple of dancers, and it's all hard entry; you can't get in unless somebody — unless I swipe, I'm the only one with a card, so I have to open the door for everybody. They text me when they arrive. I had a student from Queens College who was supposed to come and watch rehearsal for an assignment of hers, and ten minutes before rehearsal, I'm waiting for the dancers to text me, I'm doing yoga out in the hall because I can't get in the studio yet, I get an email from the presenter, who's been hiding from me for the last five months, not answering emails about anything; suddenly, do you have liability insurance? Ah. No, do I have to? Yes. So then I have to start madly trying to organize liability insurance seven minutes before rehearsal. The dancers come, and I'm getting all these emails about liability insurance, and I have my phone turned up, because I need to know when people need to get in the building. It's interrupting and we're trying to rehearse, so I turn it off - I put it into airplane mode, the student from Queens College arrives and she can never get into the building; she can't contact me... ${ }^{108}$

Lamb's multi-tasking gymnastics just to hold one rehearsal bear little resemblance to the organized predictability of rehearsing within a large company. Of course, it could be argued that Lamb chose these gymnastics for herself — that, instead of working with her own dancers, on her own concert, she might have done some commissioned work for a larger ballet company, as she has before. In other words, the comparison between Peck's work at City Ballet and Lamb's work with her own company is not fair. But this ignores the distinction between the isolated commission and work with a company on a continued basis, as resident choreographer. Lamb's self-constructed choreographic residency bears more resemblance to Millepied and Peck's work as resident choreographers than does a commission, as it involves working with dancers with whom the choreographer is familiar, and without the constraints of unfamiliar expectations and foreign company culture. Lamb did not end up as the resident choreographer for one of the companies for which she created commissioned work (as was the case with both Millepied and Peck), and had to perform the extra administrative tasks requisite to managing her own group. The invisibility, and additionality, of these comprise an

108 Ibid. 
additional burden to her, as a consequence of not benefitting from the promotion and attention received by the male choreographers.

Nonetheless, Lamb did not find that her administrative job detracted from the quality of her artistic work. Instead, the effort of doing both administrative and choreographic jobs aided the spontaneity of her creative process. Lamb told me, "I'm never bored, I don't have any time to look at facebook and get resentful of other people." ${ }^{109}$ Lamb said that, despite feeling scattered in the midst or preparations for a show, her sense of tiredness actually made the act of choreographing slightly easier, since being exhausted helped her work spontaneously. This was made easier by her creative work on the concert over the last summer, previous to her upcoming residency.

LeCrone, too, does not work with a large company, and must do all of her own administrative work. "I think the biggest advantage for... the choreographers that come from these big companies is that they can use those resources: they have access to studio space and their friends." 110 Unlike Millepied and Peck, LeCrone has her own group and does not choreograph for large companies. This means that she must do administrative work in addition to her artistic work to support the creation of her dances. LeCrone spends a significant amount of time and effort on logistics such as reserving space and scheduling dancers, which takes time and energy away from the creation of choreographic work. ${ }^{111}$

Freelancing presents more logistical problems than working for a large company. Access to space is particularly important for ballet, which demands hours of rehearsal time in addition to a marley floor and the ability to use rosin. A permanent space, however, is financially unfeasible for small groups like LeCrone's. Similarly, choreographers for larger companies, like Peck, have the ability to work with classically trained dancers on a consistent basis. When LeCrone first started choreographing, she had to re-hire dancers every time she started a new project, which meant that she needed more rehearsal time for the dancers to adapt to her and each other. Likewise, larger companies provide understudies, whereas LeCrone has to do without. This can have ramifications for her work: in October 2016, she had to pull out of a contracted show because one of her dancers got injured. ${ }^{112}$

Similarly, large companies have an administrative infrastructure to deal with the logistics of putting together a production. Notably, after so many years of work, LeCrone still does not have an assistant to lighten the administrative burden. The logistics of reserving space and scheduling dancers can place considerable pressure on choreographers unrelated to artistic creation: LeCrone works fifteen-hour days in the month or two before a show to pull everything together. "What gets overwhelming here

\footnotetext{
${ }^{109}$ Ibid.

110 Emery LeCrone, interview.

${ }^{111}$ Ibid.

112 Ibid.
} 
are those little things, like when you call and reserve the studio space and you have six dancers and... three hours to finish a piece and you get there, and someone messed up their book-keeping, and you don't have the space." Likewise, LeCrone has to work around the disparate schedules of dancers with many commitments: "That's one of the challenges in New York: you don't own anyone's time." For her upcoming show at the Joyce Theater, LeCrone will rely on intensive two-week rehearsal periods when all of her dancers are available, instead of the more consistent rehearsals she might have at a larger company. ${ }^{113}$ Despite these difficulties, LeCrone enjoys working with her own dancers, as opposed to dancers in other companies, because they share a history and have developed a rapport.

The problem, then, is not that administrative work detracts from the quality of the choreographic work produced by Lamb and LeCrone, but rather that it comprises a second job, for which neither receives recognition or compensation. Getting compensated for creative work is difficult enough, and these women are certainly not compensated additionally for their simultaneous role as producer of one's own concert. Likewise, without the luxury of being able to swoop into a studio, "score in hand,"114 the work of putting together a dance, or a show, becomes significantly greater, with the same end result. For these women, there is double the work, for - if Alastair Macaulay is taking an anomalous break from misogyny - the same amount of recognition.

Unlike Lamb and LeCrone, Pickett does not work as a freelance choreographer. The struggles of freelance work do not interest her: "I knew I didn't want to struggle to find two days in the theater and work with eight dancers with minimal pay."115 After Pickett retired from the Forsythe company, she did not plan on re-entering dance at all.

Following her re-entry into ballet with the Boston Ballet, Pickett worked almost entirely on commissions, because they were better funded and the dancers better paid. "I'm far too intense for this to be an extracurricular activity," Pickett says, and thus does not consider the benefits of hiring her own dancers in her own company not worth the sacrifice in pay, and what she perceives as the resulting sacrifice of quality in her work. As a result, Pickett does not have her own group, but continues to work on commissions and special projects for other companies.

\section{The Search for Career Continuity}

From my interviews with all three women choreographers, another dominant theme emerged in the constant search for work - and the impending discontinuity of career, absent that searching. All have had significant experience as choreographers, and yet still have to actively seek out work. For Lamb, this was immediately apparent. Lamb

113 Ibid.

114 "Plainspoken: On Mark Morris," The Nation, accessed April 26, 2017, https://www.thenation.com/ article/plainspoken-mark-morris/.

115 Helen Pickett, phone interview with the author, November 8, 2016. 
started choreographing in 2009 with a commission for Hubbard Street Dance, won via a choreographic competition, which never led to the kind of windfall of commissions that a choreographer of her caliber might have expected:

When I moved here I danced with Chris Wheeldon, in his company, I had that Hubbard Street II commission that year... and I think that I thought that after that one, that things would just sort of start to rain onto me from heaven, which wasn't really what happened. I wasn't prepared for how much I was going to have to keep on making things happen. ${ }^{116}$

Note that the "raining... from heaven" was precisely the result of Peck's first commissions for City Ballet. In contrast, Lamb had to continue to seek her out her own work, and still does. The note of surprise in her comment - "I wasn't prepared" indicates not a naiveté (it would be ignorant, if not foolish, to call Lamb unintelligent), but an awareness of the trajectories of other choreographers after their first major commissions, and an expectation, conscious or otherwise, of the same.

As was the case with Justin Peck, LeCrone was encouraged by mentors to start choreographing. LeCrone started her ballet training as a child and attended a performing arts high school. Directly after graduating, LeCrone joined North Carolina Dance Theater, where she danced for two years. At the time, the company performed predominantly Balanchine works, but some contemporary ones as well. The directors of the company encouraged LeCrone to choreograph: "I was encouraged at North Carolina Dance Theater to start choreographing," LeCrone says, "because Jean-Pierre [Bonnefoux] and Mark Diamond, the directors of the company, were always really adamant about giving people in the school and apprentices the chance to explore composition." As a result of this encouragement, LeCrone took composition classes and began to explore creating work. ${ }^{117}$

Unlike Peck, LeCrone did not keep dancing full time as she began to spend more time on her work as a choreographer. LeCrone began choreographing works for herself and her friends when she moved to New York in 2008. LeCrone says that her choreography took priority in her career: "My dancing started to slow down, and the choreographing started to increase." At the time, few pick-up companies existed, so LeCrone presented her work at studio performances and choreographic festivals. ${ }^{118}$ Over the past ten years, this has led to freelancing, creating commissioned work for many

\footnotetext{
116 Gabrielle Lamb, interview.

${ }^{117}$ Emery LeCrone, interview.

118 Ibid.
} 
companies. Now, she choreographs primarily for her own company, Emery LeCrone Dance. ${ }^{119}$

Before the establishment of her company, LeCrone started out creating commissioned work for companies and schools, which tended to come more from preexisting connections than active networking. "I still believe that the dance world is extremely small so many of my commissions came from personal connections.... It really for me wasn't a lot of resume building and promotion." Potential employers came to see performances or rehearsals, or would receive a recommendation, which allowed LeCrone to overcome the hesitancy of artistic directors to take risks on unknown choreographers. These early commissions allowed LeCrone to build up a New York fan base and start working with her own dancers. ${ }^{120}$

But commissions did not lead to the same career continuity for LeCrone that did the early commissions of Millepied and Peck. Whereas she claims that self-promotion was difficult, LeCrone clearly worked hard for her success: "When you first start you feel like you have to do everything, because if you don't do everything, you don't matter."121 As a choreographer, LeCrone has worked in a wide variety of contexts. In 2008, she participated in the National Choreographers Initiative, and in 2009, created Aphorismós for the Columbia Ballet Collaborative, a student-run dance company at Columbia University. In 2010, LeCrone created Divergence for Oregon Dance Theater; in 2011, Outflow Boundary for North Carolina Dance Theater and With Thoughtful Lightness for the Guggenheim Works and Process series. The same year, LeCrone was invited to participate in the New York Choreographic Institute, and in 2011-2012, in the New York City Center Choreography Fellowship Program, along with choreographers Andrea Miller and Shen Wei. ${ }^{122}$ In 2012, LeCrone created Aria for Jacoby and Pronk and In Pursuit of Falling for the Juilliard School. In 2013, LeCrone created Figurant for St. Louis Ballet and Partita No. 2 in C Minor for the Youth America Grand Prix Gala. ${ }^{123}$ LeCrone has also created pieces for Barnard College, the University of North Carolina School of the Arts, Goucher College, the Hartt School, and other organizations. ${ }^{124}$

Despite her ten years of choreographic experience, LeCrone must still actively seek commissions. Although LeCrone claimed to rely less on active networking, she also

\footnotetext{
119 "Emery LeCrone Choreography: Bio,” accessed November 21, 2016, http://emerylecrone.com/web/ bio/.

120 Emery LeCrone, interview.

${ }^{121}$ Ibid.

122 “Interview: Emery LeCrone, Choreographer," DanceTabs, July 6, 2012, http://dancetabs.com/2012/07/ interview-emery-lecrone-choreographer/.

123 “Emery LeCrone Choreography: Works,” accessed November 21, 2016, http://emerylecrone.com/web/ concert-dance/.

124 "Emery LeCrone Choreography: Bio."
} 
noted that she has to seek out her own work. "That's the hard thing about doing freelance, whether you're a woman or man - you have to go find your work, and you're not employed full-time." This implies that LeCrone had to employ at least some form of networking or promotion to sustain career momentum. ${ }^{125}$

LeCrone also mentioned a momentary loss of momentum that might be foreign to a choreographer like Peck or Millepied. "When you're a new person on Instagram or something you get all of these followers, and then slowly it filters out, and you're less of a hit." Despite her impressive resume, she spoke of a mid-career transition with a certain loss of momentum, when she was no longer the next new thing. She has also become more discerning with respect to the commissions she accepts. Saying no to commissions makes her feel less busy, and thus less in demand: "If I had the ability to accept every commission that I'm offered and not take any setbacks... my career would be accelerating faster." Ultimately, however, being more discerning about her commissions allows LeCrone to spend more time on each project, and thus make it more "honest" and "focused." It also allows her to spend more time with her own company. ${ }^{126}$

LeCrone was hesitant to frame her freelance work as a choice. "In a sense, it's a choice because I guess I've realized that, for me, long term right now, it's more valuable to be here in New York with a small group of people than to go away and have to come back and rebuild." ${ }^{27}$ LeCrone said that she would gladly accept a commission from a major company, however, if given the opportunity. "If Paris Opera called me tomorrow, I would definitely go." 128 This hasn't happened for her - yet. Although LeCrone may have participated in the New York Choreographic Institute, an NYCB commission did not follow, nor has she received many - if any - commissions from the NYCB "family" of companies that provided a critical proving ground for Peck. "My work right now is still definitely a product of what's possible. You take the projects as they come, and you make the projects when you don't have any."129

Helen Pickett has also worked relentlessly to pursue a choreographic career by marketing her work to companies:

When I got No's, part of me withered, but part of me said, inside... I'm going to show you. I sent out hundreds of DVDs, I wrote every director, I used my connections.... I took jobs, even if they were low-paying; I took commissions to learn how to be a choreographer. ${ }^{130}$

\footnotetext{
125 Emery LeCrone, interview.

126 Ibid.

${ }^{127}$ Ibid.

128 Ibid.

129 Ibid.

${ }^{130}$ Helen Pickett, interview.
} 
This echoes the theme present in Peck's career, of using networks to gain experience, and thus to become a better choreographer. Pickett's self-promotion to take advantage of those networks stands in stark contrast, though, to Peck's relatively easy access to them. Even though Pickett had similar connections, she had to promote herself to, instead of being recruited by, said connections, to take advantage of them. This is evidenced by the range of work accepted by Pickett — "I took jobs, even if they were low-paying" - to continue improving as a choreographer. Pickett did not choose selectively where she would create her next ballet, and thus has created work for companies far smaller than the smallest company that employed Millepied, or Peck.

Pickett's self-promotion allowed her eventually to build a successful career out of commissioned work. For Pickett, choreographic jobs led to other jobs, but she continues to pursue her career with a strong degree of self-promotion. Even now, she says, "I send things fifteen times to the same company because at some point they will say yes." ${ }^{131}$ She has agreed to commissions beyond the traditional scope of ballet, including several short films, an opera, and a ballet to "pop-sounding music" in London.

Pickett cites no hesitation from company directors to work with a female choreographer, claiming that European directors are more likely to take risks. "I have never had strange, under-the-radar comments [from directors] about being a woman." 132 She has, however, encountered resistance from dancers. "I actually had a dancer in a big company say, 'I just work better with men, Helen.' And I said, 'So do you want to be in the ballet?"' This raises the question, if women become so accustomed to working with male choreographers that they do not believe they can work well with women, would they ever be able to perceive themselves as choreographers? Pickett attempts to counter this dynamic by setting an example: "I am out there forging the path for young women and men - to see. They need to see a woman in power." ${ }^{\prime 133}$ For dancers, the choreographer is somebody "in power."

It would be incorrect, however, to assume that all female choreographers would achieve success, and thus win greater parity, if they simply promoted themselves enough — or as much as LeCrone and Pickett. This infers that Millepied and Peck have achieved success solely due to their pursuit of opportunity, and completely ignores the structural inequalities that may preferentially promote men as ballet choreographers over women. Whereas Pickett claims that she did not encounter any overt hesitation to hire her because of her gender, the fact remains that she would likely not have had to pursue commissions quite so actively, had they materialized as they did for Millepied and Peck.

Pickett acknowledges the difference between her own career and that of many successful male choreographers. "Anybody who has had any career," Pickett claims, "has

\footnotetext{
131 Ibid.

${ }^{132}$ Ibid.

133 Ibid.
} 
been unabashedly instrumental in their own trajectory." 134 But Pickett acknowledges that unprecedented institutional support may have benefitted the career trajectories of certain male choreographers (such as Peck), in ways that such support has not also benefitted female choreographers such as herself. Peck was talented, Pickett says, but was also somehow anointed by those in power as "the next great thing."

\section{Conformity of the Corps}

From my conversations with the women choreographers, two main reasons arose for the disproportionate number of men who become choreographers: one, the demands on women in ballet do not leave the time or energy to pursue choreography, and two, women do not choose to become choreographers, but focus instead on becoming principals or soloists. While the first of these explanations acknowledges an institutional preventative factor, the second finds the cause of inequality in the behavior of its victims, without examining the processes that inform that behavior in the first place. Thus, we must ask, how much is the choice not to pursue choreography a result of institutional structures?

Working as woman in a ballet company requires an enormous input of time and energy, and as mentioned in the introduction to this paper, the popular press often attributes the lack of women in ballet choreography to this lack of extra time. LeCrone's own "slow down" of dancing as she began to choreograph corroborates the idea of time as a constraint preventing women from entering choreography. Women in ballet must compete against each other to get promoted, and becoming a principal dancer requires an immense amount of physical and mental dedication that may leave little time or energy for anything else. Explaining gender inequality as a product of time constraints on women, however, fails to acknowledge other institutional dynamics, such as those that may prevent women from seeing themselves as choreographers or prioritize men. ${ }^{135}$

LeCrone explained that even if given the time, most women would choose to become a principal, not a choreographer, whereas men usually make the opposite choice. "It just so happens that Benjamin [Millepied] and Chris [Wheeldon] and Justin [Peck] and Liam Scarlett - and most of these male choreographers - they excelled to a certain point as a dancer, but they don't go on to be Baryshnikov." 136 Thus they choose to pursue choreography. In contrast, LeCrone thinks that women rarely make that choice. "I haven't seen a woman yet who gets to that point as a soloist or as an almost-principal ballerina, who goes, you know what, I'd rather make work." Instead, those women in ballet who

\footnotetext{
134 Ibid.

${ }^{135}$ Emery LeCrone, interview.

136 Ibid.
} 
enter choreography tend to do so after a career as a principal. Thus, LeCrone believes, men are somehow more able to walk away from "that sort of stardom." 137

Simply accepting this as a difference between male and female dancers risks subscribing to fundamentally problematic schemas of natural differences between men and women (as described earlier). To avoid this, we must probe the institutional dynamics that cause women to make the choice not to choreograph in the interest of becoming principal dancers.

First, the expectation of conformity for women in the corps may constrain creativity. Dancing in the corps involves a uniformity that requires a significant amount of training and may mitigate creative impulses. LeCrone said that ballet schools teach young women to conform: "You're taught, keep your mouth shut, and wait until you're told where to go." Companies perpetuate this, and require women to aspire to uniformity "until you're Wendy Whelan. Then you can be different. But right now, we want you to be the same. And [when] you're the best at being the same, you'll get promoted."138 Companies enforce this image of conformity because it is integral to the identity that they sell to the general public. ${ }^{139}$ Ultimately, LeCrone believes, this is a very damaging mindset for a choreographer to have, because it prevents the processes that facilitate choreography. Because of this, LeCrone herself did not start creating her own dances until she started taking master classes and working with contemporary choreographers. "Messing up and trying something completely unexpected is actually the genesis of creation. You have to explore." 140 The conformity of the corps prevents the innovative risk-taking required to produce new and interesting work. This does not preclude the emergence of women with a strong independent mind, but rather relates to the fact that independence of mind tend to be discouraged.

Lamb told me that Les Grands Ballets actively stopped supporting choreography, because they were "afraid of injury." Lamb told me,

...one of the reasons I ended up leaving my company was that they were not going to be having choreographic workshops anymore, they were trying to control what dancers did; they were afraid that we'd get injured doing anything besides the actual paid work of the company. ${ }^{141}$

This instance bridges the distinction between the technical conformity of the corps and behavioral conformity. To support a uniform ("uninjured") corps de ballet, the

\footnotetext{
137 Ibid.

138 Ibid.

${ }^{139}$ Lynn Garafola, personal communication, November 22, 2016.

${ }^{140}$ Emery LeCrone, interview.

${ }^{141}$ Gabrielle Lamb, interview.
} 
company actively controlled the dancers' choreographic opportunities, and thus their behavior. The question of whether the company decided to halt the choreographic workshops due to actual concern about injury, or for some other reason, does not bear any real significance, as the significance of the incidence lies in the active control over the bodies and behavior of its dancers. The "actual paid work of the company," the work as performers, most of whom would be corps members, exerted tangible control over the dancers' behavior, via the negation of choreographic opportunity.

As a corollary, men tend to perform partnering or solo roles, and thus receive greater individual attention and are permitted greater individuality. LeCrone believes, empirically, that the scarcity of male dancers ultimately provides a mechanism for their promotion within companies. "The men actually get more promotion as dancers and more accessibility because there's just fewer of them in the field." Men tend to interact with choreographers in more intimate settings, whereas, as LeCrone said, "You don't really get that when there's forty-two swans in the room."142 Individual attention can promote the independence that facilitates choreographic exploration.

Throughout her career, Helen Pickett has actively defied the conformity of the corps, remaining an artistic individualist. Pickett started working choreographically when she joined William Forsythe's company and began to participate in his collaborative process. At twenty years old, she "fell into the lap of using your own brain, contributing to the conversation, being within a society that promotes individualism and rebelliousness." 143 She cites her rebelliousness at the San Francisco Ballet school as indicative of her curiosity, which she cites as important to her as both an artist and "as a human being." Interestingly, when Forsythe actually encouraged Pickett's rebellious curiosity, at first she felt like she had been "thrown through a loop." "I wanted to be told what to do," and instead, Forsythe wanted his dancers to think for themselves, be responsible for their own work, and create. ${ }^{144}$

Pickett's creative agency extended beyond her work with Forsythe. At 31, she retired from her job as a performer to pursue an acting career. Pickett did not want to become a "default teacher," a rather striking claim that suggests an expectation for the career trajectory of female professional ballet dancers. She participated in art films, had a band in Frankfurt (where Forsythe's company was based), and wrote. Pickett performed some small parts with the Wooster Group and created solos for the Ailey school. When Pickett re-entered professional ballet with a commission from the Boston Ballet in 2005, she continued to write. Eventually she earned an MFA in Dance under Thomas DeFrantz at Hollins University.

Pickett attributes her creative agency in part to coming from an artistic family. She claims that she always needed to make art: "I'm voracious when it comes to new

\footnotetext{
142 Emery LeCrone, interview.

${ }^{143}$ Helen Pickett, interview.

144 Ibid.
} 
information." ${ }^{45}$ As an actor, Pickett continued to write and to move, because, "if you have to do something, you will" 146 - a creative imperative that indicates both Pickett's own sense of self and her active pursuit of a career. Pickett claims that she did not start choreographing earlier because of a fear that after working with Forsythe, a seminal figure in recent ballet history, she, by comparison, might not have anything to contribute. She claims that a phone call with Mikko Nissinen, Boston Ballet's artistic director, helped unpack that fear and enabled her to start creating movement again.

In addition to her creative upbringing, several other factors also contribute to Pickett's drive to create work. One is the need to coach:

If I can help dancers reveal themselves to themselves, and find out how they can be the most creative, I love that work.... Choreography was a way I could get into the studio, be creative, work with people, make a difference, and influence people to become the artist they might not realize they could be. ${ }^{147}$

Again, this reveals not only Pickett's sense of self, but also her rejection of conformity in favor of working with dancers as individual humans, in the same manner as Forsythe when Pickett was a member of his company. Pickett likes to encourage women, especially, and supports the careers of younger women in addition to putting tremendous effort into her own.

Part of Pickett's success in defying the conformity of the corps may be attributable to her willingness to decline commissions, or dancers. Pickett attributes her success to creating good relationships with people and to her level of preparation as well as a willingness to decline certain projects and performers. Pickett says that she will decline a commission if the director of the company suggests music that she does not connect with, if she does not get enough time with the company, or if she already has too much on her plate. "If I have five new commissions a season, two will suffer." 148 When Pickett declines dancers, she tells them what to work on to become better suited to her type of work.

Learning to say no was a huge freedom for Pickett, and indicative, she claims, of differences in societal training for men and women. Women in ballet are taught always to accept and say yes, Pickett claims, and tend to be surprised when their choreographic work is sought after. Male choreographers, by contrast, seem more accustomed to success: "You rarely read, 'I'm so terrified, I'm so thankful,' from men," Pickett says, whereas this seems to be a typical response for women who get selected to create work

\footnotetext{
145 Ibid.

146 Ibid.

147 Ibid.

148 Ibid.
} 
for large ballet companies. This sort of self-deprecation, Pickett notes, is a way to broadcast femininity via fear of authority, something that Pickett claims gets taught to women from a young age. "Don't broadcast that you're scared, don't broadcast the female thing," Pickett says. ${ }^{149}$ Again, this speaks to institutional control over behavior in the form of modes of expectation, and the training to fulfill that expectation. Pickett claims to have escaped this pressure via her unusual career trajectory: "I have quite purposefully stepped outside of the ballet realm throughout my life so that it wasn't this encapsulated, closed-off thing." 150 The "encapsulated, closed-off thing" to which Pickett refers seems to be a system of institutional control, whereby the only mode of escaping such control is to step outside of the institution.

\section{A Minority of Men}

Maxine Leeds Craig's sociological work on men in dance identifies negative social perceptions of homosexuality that surround male dancers. In Williams' study, negative cultural stereotypes kept men out of librarianship, kindergarten teaching, social work, and nursing. Similarly, Craig finds that negative stereotypes surround white men who dance, in both social and professional contexts. Craig writes of dancing as a failed masculinity: "While the athlete is a masculine ideal, the man who dances professionally risks being perceived as the perfect example of a type of failed masculinity." ${ }^{\prime 51}$ This failed masculinity results from the perception of male dancers as homosexual, as the onstage objects of male gaze and pleasure, as opposed to the embodiment of male strength, heroism, and supremacy, as is the case with sports stars.

Craig identifies the perceived feminization of the male dancer as an additional stigma, compounding the stereotype of the homosexual male ballet dancer. Just as homosexuality is a failure of the project of masculinity, so too is feminization, which Craig identifies as a similar, but distinct, phenomenon. Craig writes that grace is a defining aspect of femininity, and that the perceived foundations of ballet technique in grace may belie the masculinity of ballet dancers. Ballet, in its perceived grace, is coded as female; in a female-coded art form, masculinity becomes impossible. As a result, heterosexual men reject ballet, Craig writes, as a means of asserting their masculinity: "When ballet became feminine and queer, men who wished to be perceived as normal stayed away from ballet studios and stages." 152 Note that the behavior described by Craig is in reaction to negative cultural stereotypes - avoidance of ballet to be "perceived as

\footnotetext{
149 Ibid.

150 Ibid.

${ }^{151}$ Maxine Leeds Craig, Sorry I Don't Dance : Why Men Refuse to Move (New York, NY: Oxford University Press, 2014), 8.

152 Ibid., 13.
} 
normal" implies the perception of abnormality, or queerness, in those who participate. This reflects precisely the negative cultural stereotypes that Williams identifies as keeping men out of her four professions.

Organizations work against these negative perceptions of the male ballet dancer by linking grace with power, both physical and artistic. Craig writes, "The gender coding of dance, and its association with men's homosexuality, has long been treated as a problem by dance advocates who felt that a feminized art form lacked legitimacy." ${ }^{153}$ To lend the form greater legitimacy, Craig writes, twentieth century dancers and dance instructors worked to align dance with visibly masculine traits. Craig identifies this alignment in the association of grace with physical power in the development of male technique. But the association of the male ballet dancer with artistic power may accomplish the same ends, as is suggested by Williams' study, such that the artistic power of choreography surmounts the "femiphobia and homophobia"154 identified by Craig that surround men who dance. By prioritizing their careers as choreographers, then, ballet organizations may legitimate the men who dance for them, similar to the libraries and hospitals of Williams' study.

\section{Conclusion}

As evidenced by the statistics analyzed here, ballet in the upper echelon of companies is predominantly a female profession, but the majority of its choreographers are men. This satisfies the condition of the glass escalator that dance is predominantly female, as well as providing evidence that men are preferentially promoted as choreographers. The career trajectories of Millepied and Peck suggest a high degree of institutional hiring and promotion in the form of access to large companies, ${ }^{155}$ continuous commissions for their work, and plentiful critical attention. In contrast, the women choreographers interviewed for this research all spoke of the difficulties of working with their own small groups, relentless self-advocacy to get new commissions to get new commissions or new opportunities to develop their work, and a conformational pressure that constrains creativity via a constraint on individuality. Why do Peck, Millepied, and other male choreographers receive so much opportunity in comparison with their female peers?

Three main mechanisms seem to contribute to the differential success of men and women: the "second job" of administrative work, a discontinuous career as a result of less recruitment from networks, and the conformity of the corps de ballet. For Lamb and LeCrone, administrative work comprises an invisible second job, for which they receive neither compensation nor recognition. All three women would likely not have had to

\footnotetext{
153 Ibid.

${ }^{154}$ Ibid., 110.

155 ...especially in the opportunity to serve as resident choreographers at major companies within the first decade of their choreographic careers.
} 
pursue commissions so actively, had commissions fallen into place in the way that they did for Millepied and Peck. Finally, the conformity of the corps comprises a system of institutional control that constrains the creative agency of female ballet dancers.

From the interviews with Lamb, LeCrone, and Pickett, the training to become a member of the corps seems to exert a conformational pressure that mutes individuality. Instead of construing the resulting lack of female choreographers in ballet, however, as due to a lack of interest or motivation, Pierre Bourdieu's idea of habitus provides a framework by which the embodied conformity of the corps is an institutional structure of inequality. Sociologist Joan Acker presents the concept of the "ideal worker" as a compliant, hardworking, non-individual. "The ideal worker for many jobs is a woman, particularly a woman who, employers believe, is compliant, who will accept orders and low wages." 156 This may be the case with women training for the corps, for whom the traits of Acker's ideal worker are requisite to their job.

Habitus, in its general form, is acquired early in life as a result of continuous confrontation with a certain environment and social order. Bourdieu writes of habitus as "schemes of perception, appreciation, and action" that enable people to perform acts of practical knowledge based on "identification and recognition of conditional, conventional stimuli." ${ }^{157}$ In other words, habitus is the embodied memory of the social structures and institutions that guides a person's physical and mental interaction with the world. Bourdieu writes of a general habitus, acquired in early life, and a specific habitus acquired through interaction with rules and training imposed by organizations. ${ }^{158}$ If a person's general habitus transitions easily to the specific habitus required by a certain job or organization, they may appear to be naturally suited to that job. By using the general habitus of hegemonic femininity to conform to the specific habitus of a ballet dancer, women may place themselves at a disadvantage by making them appear naturally suited to acquiescence and conformity. "We are still training women to be pretty and nice instead of being exceptional and beautiful leaders," says Pickett.

Within ballet, the discipline and schooling that comprise ballet training result in an institutional habitus, or a mode of behavior specific to a ballet institution within the broader field. ${ }^{159}$ Institutional habitus causes a ballet dancer to become comfortable within a particular school or company, as they become accustomed to, and part of, that institution's culture. ${ }^{160}$ The modes of discipline and training at the various ballet schools may result in an institutional habitus, wherein the culture of a particular organization may

\footnotetext{
156 Joan Acker, Doing Comparable Worth : Gender, Class, and Pay Equity (Philadelphia: Temple University Press, 1989).

157 Pierre Bourdieu, Pascalian Meditations (Cambridge, UK: Polity Press, 2000), 138.

158 Bourdieu, 164-67.

159 Steven P. Wainwright, Clare Williams, and Bryan S. Turner, "Varieties of Habitus and the Embodiment of Ballet," Qualitative Research 6, no. 4 (November 1, 2006): 543.

160 Ibid., 544.
} 
become written onto the bodies of those who train there, providing a common embodied knowledge. Sociologists Steven P. Wainwright, Clare Williams, and Bryan S. Turner extend this by claiming a further, even more specific choreographic habitus, acquired through working to conform to the expectations of a particular individual. ${ }^{161}$ In ballet, this seems to manifest itself in different techniques, most notably the Balanchine culture written onto the bodies of the dancers in the network of Balanchine repertory companies.

From my interviews with LeCrone and Pickett, one important distinction emerges between ballet and the professions studied by Williams: whereas choreographers are often promoted to the position after a career as a performer, choreography is nonetheless its own subfield of ballet. Helen Pickett believes that choreography is indeed its own subfield, but not quite a separate profession. She thinks that the details and subtleties of the art form acquired as a performer greatly inform a choreographer's work, such that the experience of performance becomes requisite to creating good work as a choreographer. Thus the glass escalator seems to apply to the promotion of dancers to the position of choreographer, but because the profession of choreography is so distinct from that of performing, additional dynamics inform the experience of choreographers in major companies.

Specifically, the glass escalator creates female tokens in the upper echelons of ballet choreography by preferentially promoting men so much that the proportions of men and women in the respective fields become flipped. In other words, while women are in the majority in the broader field of ballet, women choreographers actually become tokens in the subfield of choreography. Maxine Leeds Craig writes that ballet organizations may legitimate the men who dance for them by prioritizing their careers as choreographers. But if choreography becomes a separate subfield from that of performance, it may even become a masculine profession, thus legitimating the men who take part. Thus women choreographers suffer from the consequences of tokenism: As a minority in this smaller field, women choreographers get assigned a symbolic position, which may ultimately obscure their own, individual work. This is what Rossabeth Moss Kanter refers to as "symbolic consequences," wherein token women become representatives of all women and are not permitted their own individuality, and their failures become the failures of women in general. The "all-women" bill for female choreographers, in which if one piece does not work, the whole program gets dropped, ${ }^{162}$ evidences the presence of these symbolic consequences for female choreographers.

The focus on "female choreographers" also subjects women in ballet to what Kanter refers to as "boundary heightening," or the emphasis of tokens' distinctness from the majority. This functions to consciously or subconsciously exclude token women from the networks of men in the same profession, such that token women are always viewed as outsiders. This is seen from the career trajectories of the men and women analyzed in this

\footnotetext{
${ }^{161}$ Ibid., 545.
}

162 Lauren Wingenroth, "Moving Past Patriarchy: How Embracing Female Choreographers Can Transform the World of Ballet" (Undergraduate, Columbia University, 2014). 
study, wherein male choreographers were recruited from within organizations while the women tended to come from outside. Often, the female choreographers interviewed here received commissions for companies with which they never danced; the men began their choreographic careers within the companies where they had much of their performing career. Boundary heightening also limits access to networks, which, as seen in the career of Justin Peck, provide a powerful platform for choreographic experimentation, and thus, development of talent. Simply more female choreographers thus does not provide an adequate solution to the problem of gender disparity in ballet choreography, as boundary heightening limits access to networks on a social scale.

Further, the framing of "female choreographers" instead of simply "choreographers" implicitly assumes that choreography is male, and thus requires "female" as a modifier if otherwise - just like "female scientist,"163 "female president," etc. Thus, the very study of "female choreographer" indicates broader societal expectations that men naturally occupy positions of authority, ${ }^{164}$ and thus normalizes their occupation of these positions. All-female choreographer programs, articles in the press, even this study, continue to treat women creating ballet as a divergence from the norm, and as such, inadvertently perpetuate the very norms that they attempt to disrupt. In other words, the very study of "female choreographer" instead of "choreographer" indicates broader societal expectations that men naturally occupy positions of authority. Thus the glass escalator not only preferentially promotes men, but subjects women who overcome this preferential promotion to the dynamics of tokenism.

Yet ignoring gender inequality also normalizes it by implicitly accepting it as immutable. This raises a fundamental issue with this study: examining female choreographers perpetuates natural differences schemas. To resolve these opposing forces, LeCrone believes that companies need to start taking risks and hiring new people, giving emerging choreographers the resources to create excellent work. LeCrone hopes that the work will speak for itself: "When most people come to see a show, hopefully, they're not thinking that a woman made this or a man made this, but rather that they're having an experience and perceiving the work." 165 While this may ignore societal biases on the part of the audience, it speaks to the fact that hiring processes comprise a major hurdle to gender equality in ballet choreography. Women cannot develop quality work if companies don't take risks on new choreographers who haven't yet developed a name for themselves. Otherwise, they are expected to make their best work with the fewest

\footnotetext{
163 As a white women, I was the recipient of the "diversity" grant for a doctoral program in ocean chemistry.

${ }^{164}$ Again, this likely applies specifically to privileged white men, although the proof/complication of this lies outside the scope of this study. The large presence of gay men in the field may or may not preclude gender identity/ sexuality as a factor.

165 Emery LeCrone, interview.
} 
resources, ${ }^{166}$ which ultimately prevents women from entering the top tiers of ballet choreography.

"It is tempting," wrote Kanter, "to locate at least some of the causes of injuries in the actions of the injured." In other words, it is easy to blame the struggles of an individual - whether it is her failure to become an internationally recognized choreographer, or to get elected president of the United States- on her own actions and behavior. And yet doing so ignores the institutional mechanisms that preferentially promote certain types of people to positions of power. In recognizing these mechanisms, it becomes possible to de-normalize them, and thus to create the potential for the mechanisms of unequal access to positions of authority to be questioned and overcome.

166 Joshua Beamish, Troy Schumaker, and Emery LeCrone, "Emerging Choreographers" (Contemporary Ballet: Exchanges, Connections, Directions, Barnard College: Society for Dance History Scholars, May 21, 2016). 


\section{Acknowledgements}

I gratefully acknowledge professor Lynn Garafola for her continuing support and guidance of this project, brilliant editing, and countless conversations on dance history and politics. I would also like to acknowledge Gabrielle Lamb, Emery LeCrone, and Helen Pickett for their thoughtful answers to my many questions about working as a choreographer in ballet. I offer a heartfelt thank you to the Barnard College Dance Department for supporting the daily practice requisite to a deeper understanding of this art form, and for the continued support of the faculty throughout my dance education at Barnard. Finally, I would like to acknowledge sociology professor Teresa Sharpe for inspiring this project in her course on the Sociology of Work and Gender in Spring 2016, in which I first learned about tokenism, the glass escalator, and much of the other sociological theory applied in this paper. This project was made possible by the Hungarian Pastry Shop on Amsterdam and $111^{\text {th }}$ Street. 


\section{Bibliography}

“2016-2017 Dancers | Joffrey Ballet.” Accessed March 26, 2017. http://www.joffrey.org/ 1617dancers.

“ABT: Dancers.” Accessed March 13, 2017. http://www.abt.org/dancers/default.asp? section=principal.

“ABT: Inside ABT.” Accessed March 13, 2017. http://www.abt.org/insideabt/ news_display.asp?News_ID=534.

Acker, Joan. Doing Comparable Worth : Gender, Class, and Pay Equity. Philadelphia: Temple University Press, 1989.

"Artists - The Dancers at Pacific Northwest Ballet in Seattle." Pacific Northwest Ballet, June 19, 2015. https://www.pnb.org/artists/.

“Balanchine: A Principal Year.” Pointe, October 2003.

“Ballet West Announces 2016-17 Season - Dance Informa USA.” Accessed March 26, 2017. http:/www.danceinforma.us/articles/ballet-west-announces-201617season/.

"Ballet West Launches New Works From Within: Ballet West." Accessed March 26, 2017. https://balletwest.org/news/ballet-west-launches-works-from-within.

“Benjamin Millepied.” Opéra National de Paris. Accessed November 15, 2016. https:// www.operadeparis.fr/en/3e-scene/contributors/benjamin-millepied.

“Boston Ballet - The Company | BBII Dancers.” Accessed March 26, 2017. https:// www.bostonballet.org/Home/The-Company/Dancers/Boston-Ballet-II/BBIIDancers.aspx.

"Boston Ballet - The Company | Dancers.” Accessed March 26, 2017. https:// www.bostonballet.org/Home/The-Company/Dancers/FullCompany.aspx.

Boston Ballet Media Department. "Boston Ballet Announces 2016-2017 Season,” February 17, 2016.

Bourdieu, Pierre. Pascalian Meditations. Cambridge, UK: Polity Press, 2000.

Communications Department. "New York City Ballet Announces 2016-17 Season," March 24, 2016. https://www.nycballet.com/NYCB/media/NYCBMediaLibrary/ PDFs/Press/2016-03-24_NYCB_2016-17-Season-Announcement.pdf. 
_ . "New York City Ballet Presents 2016 Spring Season Performances," March 30, 2016. https://www.nycballet.com/NYCB/media/NYCBMediaLibrary/PDFs/Press/ 2016-03-24_2016-17-Season-Announcement.pdf.

Cooper, Michael. "Breaking the Glass Slipper: Where Are the Female Choreographers?" The New York Times, June 23, 2016.

Craig, Maxine Leeds. Sorry I Don't Dance : Why Men Refuse to Move. New York, NY: Oxford University Press, 2014.

“Dancers | Pennsylvania Ballet.” Accessed March 26, 2017. http://www.paballet.org/ dancers.

“Dancers: Ballet West.” Accessed March 26, 2017. https://balletwest.org/dancers.

Desk, BWW News. "American Ballet Theatre Announces 2016 Fall Season." BroadwayWorld.com. Accessed March 13, 2017. http://www.broadwayworld.com/ article/American-Ballet-Theatre-Announces-2016-Fall-Season-20160713.

__. "American Ballet Theatre's 2017 Spring Season at the Metropolitan Opera House Announced." Accessed March 14, 2017. http://www.broadwayworld.com/ bwwdance/article/American-Ballet-Theatres-2017-Spring-Season-at-theMetropolitan-Opera-House-Announced-20161025.

Emery LeCrone. Interview with the author, New York City, November 18, 2016.

“Emery LeCrone Choreography: Bio.” Accessed November 21, 2016. http:// emerylecrone.com/web/bio/.

“Emery LeCrone Choreography: Works.” Accessed November 21, 2016. http:// emerylecrone.com/web/concert-dance/.

Escoda, Carla. “Justin Peck's In the Countenance of Kings Debuts in San Francisco to Great Fanfare.” Huffington Post, April 8, 2016. http://www.huffingtonpost.com/ carla-escoda/justin-pecks-in-the-count_b_9645470.html.

Gabrielle Lamb. Interview with the author, New York City, October 30, 2016.

“Gabriellelamb-Pwd | Bio.” Gabriellelamb-Pwd. Accessed April 26, 2017. https:// www.pigeonwingdance.com/bio. 
Garafola, Lynn. “Where Are Ballet's Women Choreographers?” In Legacies of TwentiethCentury Dance, 215-28. Middletown, Conn: Wesleyan University Press, 2005. https://academiccommons.columbia.edu/catalog/ac:199342.

“Global Visionaries | Joffrey Ballet.” Accessed March 26, 2017. http://www.joffrey.org/ global.

Graham Watts. "15 to One.” Dancing Times, September 2013.

_ . "Where Do All the Women Go?" Dancing Times, June 2014.

Harss, Marina. "Benjamin Millepied Left the Paris Opera Ballet. Now What?" The New York Times, July 15, 2016.

Helen Pickett. Phone interview with the author, November 8, 2016.

“Houston Ballet | 2016-17 Season.” Accessed March 26, 2017. https:// www.houstonballet.org/seasontickets/2016-2017-season/.

“Houston Ballet | Dancers.” Accessed March 26, 2017. https://www.houstonballet.org/ explore/artists/.

“Imagining ‘New Work’ with Justin Peck.” Miami City Ballet, March 20, 2013. https:// www.miamicityballet.org/insider/imagining-new-work-with-justin-peck.

"Interview: Emery LeCrone, Choreographer." DanceTabs, July 6, 2012. http:// dancetabs.com/2012/07/interview-emery-lecrone-choreographer/.

Ismene Brown. "I'm Having Trouble Finding an Anti-Woman Conspiracy in Dance." Coffee House, January 19, 2016. http://blogs.spectator.co.uk/2016/01/im-havingtroubling-finding-an-anti-woman-conspiracy-in-dance/.

John Munger. “A Census of New York City Dancemakers.” DanceNYC, May 1, 2007.

Joshua Beamish, Troy Schumaker, and Emery LeCrone. "Emerging Choreographers." Barnard College: Society for Dance History Scholars, 2016.

Julia Gleich, Gabrielle Lamb, Francesca Harper, and Helen Pickett. "Contemporary Ballet, Women And/As Choreographers." Barnard College: Society for Dance History Scholars, 2016.

“Justin Peck." Accessed November 12, 2016. http://www.nycballet.com/Dancers/ Dancers-Bios/Justin-Peck.aspx. 
Kanter, Rosabeth Moss. Men and Women of the Corporation. New York: Basic Books, 1993.

Kisselgoff, Anna. “A Dancer Comes Into His Own.” The New York Times, April 5, 2005.

—_ "A Robbins Premiere With a Cast To Match Its Youthful Outlook: [Review]." The New York Times. June 6, 1994, sec. C.

—. "Dewdrop Reigns in the Land of Sweets and Dreams." The New York Times. December 6, 1995, sec. C.

Kourlas, Gia. "Carefree, but Decorous All the Same: Pacific Northwest Ballet Presents 'Debonair." The New York Times, October 10, 2014.

Luke Jennings. "Sexism in Dance: Where Are All the Female Choreographers?" The Guardian (Online), April 28, 2013.

Lynn Garafola. Personal Communication, November 22, 2016.

Macaulay, Alastair. “A Return Back East to Make a Debut: L.A. Dance Project Brings Millepied and Peck Works to BAM.” The New York Times, October 17, 2014.

—_ "Review: L.A. Dance Project's Eclectic Balancing Act." The New York Times, July 27, 2016.

_. 'Review: Miami City Ballet in 'Heatscape,' a Fleeting Chase of Romance." The New York Times, March 29, 2015.

Mead, Rebecca. "Bounding Ambition: Profiles.” The New Yorker, August 5, 2013.

Milkman, Ruth. Gender at Work: The Dynamics of Job Segregation by Sex during World War II. Urbana: University of Illinois Press, 1987.

“NYCB - Dancers.” Accessed March 13, 2017. http://www.nycballet.com/Discover/ Dancers.aspx\#rank.

Pennsylvania Ballet Communications Department. "Pennsylvania Ballet Announces Revolutionary 2016-2017 Season,” March 3, 2016.

"Plainspoken: On Mark Morris." The Nation. Accessed April 26, 2017. https:// www.thenation.com/article/plainspoken-mark-morris/. 
“Repertory Season.” San Francisco Ballet. Accessed March 26, 2017. https:// www.sfballet.org/season/repertory.

Rocco, Claudia La. "Justin Peck Choreographing for New York City Ballet.” The New York Times, July 27, 2012.

Schilt, Kristen. Just One of the Guys? Transgender Men and the Persistence of Gender Inequality. London: The University of Chicago Press, 2010.

Seibert, Brian. "Justin Peck Calmly Creates a Kingdom at City Ballet." The New York Times, January 29, 2016.

"Studio Company | Joffrey Ballet.” Accessed March 26, 2017. http://joffrey.org/ studiocompany.

Sulcas, Roslyn. "Review: In Paris, a Bold Ballet Adventure From Justin Peck." The New York Times, July 13, 2016.

Taylor, Elise. “Is Justin Peck Making Ballet Cool Again?” Vanity Fair, April 6, 2016. http://www.vanityfair.com/culture/2016/04/justin-peck-ballet-cool-in-thecountenance-of-kings.

"The School of American Ballet - Timeline." Facebook. Accessed March 26, 2017. https://www.facebook.com/SABNYC/photos/a. $399587493869.183424 .36603863869 / 10151788203893870 /$ ?type=1\&theater.

Wainwright, Steven P., Clare Williams, and Bryan S. Turner. "Varieties of Habitus and the Embodiment of Ballet." Qualitative Research 6, no. 4 (November 1, 2006): 53558.

Williams, Christine L. "The Glass Escalator: Hidden Advantages for Men in the 'Female' Professions." Social Problems 39, no. 3 (1992): 253-67.

Wingenroth, Lauren. "Moving Past Patriarchy: How Embracing Female Choreographers Can Transform the World of Ballet." Undergraduate Thesis, Columbia University, 2014. 